\title{
SOCIAL SEMIOTIC GENRE: EXPLORING THE INTERPLAY OF WORDS AND IMAGES IN ADVERTISING
}

\author{
TAOFEEK OLAIWOLA DALAMU \\ Anchor University, Lagos, Nigeria \\ tdalamu@aul.edu.ng \\ ORCID: 0000-0002-5494-4854
}

\section{ABSTRACT}

This study examined the interplay of pictorial and written modes that position advertising as a multimodal genre, explainable through a social semiotic perspective. Eight advertisements of the financial, telecommunications, and beverage products functioned as devices of analysis. Nevertheless, multimodal communicative acts served as the processing tool, elucidating the meaning potentials of the advertising configurations. Having deployed a system of multimodal interacts, tables and graphs assisted in accounting for the frequency of the semiotic resources of the written modes. The analysis indicated large and highlighted fonts (Celebrating the world's no. 1 fixer), repetitions (Guinness, Maltina, real deal), and deviant constructs (EazyLoans, GTWorld) as elements of propagating intended messages. The deployment of codes $\left({ }^{*} 966^{*} 11 \#, 737\right)$ and fragmented clauses (Over N100 million worth of airtime) played some roles in the meaning-making operations. Of significance is the Guinness' conceptual "digits" of 17:59, contextualising the year, time, and channel of promotional benefits. Though questions (Have you called mum today?), offer (It can be), and minor clauses (Welcome to Guinness time) were parts of the communicative systems, statements (Terms and condition apply) and commands (Enjoy the complete richness of Maltina) dominated the entire dialogues. One might suggest that communicators should endeavour to deploy apt constructions and create eye-lines between participants as means of sensitising readers into consumption.

KEYWORDS: Advertising, Communicative Acts, Genre, Register, Social Semiotics.

\section{INTRODUCTION}

The idea of Genre cuts across disciplines. This is a reason for experiencing different kinds of writing styles and processes in communicative enterprises, operational between the writer and the target audience. Besides, the notion of genre informs one's observation of different linguistic and semiotic structures in diverse communication affairs (Bateman 2013). It is also the genre that influences or determines, to a considerable extent, the texture-cum-cohesion of text, as being an image, a word, a gaze and a colour (Jewitt 2009; Baldry \& Thibault 2006; Norris 2013; Jewitt, Bezemer \& O'Halloran 2016). That is a probable motive for Bhatia (2008) to describe genre as a conventionalised semiotic resource employed to express specific goals in a certain environment. It is deducible thus: Genre is a semiotic construct encircled with a particular setting. As genre is cross-semiotic (entailing relationships among modes); the terminology is also cross-cultural (embedding one cultural element with another) (Hall 1976, Hofstede \& Hofstede 2005, De Mooij 2015, Pérez Flores \& Muñoz Sánchez 2018). That means, genre 
seems the interrelationships of a semiotic system, interconnecting one cultural device to another in order to make meaning.

Fundamentally, literary studies have a crystal-clear record when it comes to the discourse of genre. Ezeigbo (1998) manifests the genre of literature in the form of prose, drama, and poetry. There are other genres and sub-genres in this prerogative; nevertheless, prose, drama, and poetry are the three prominently substantial bodies perhaps accommodating other types. A reference to literature becomes inevitably relevant here because of a seemingly traditional role that the study plays in communication. Perhaps, the literary text-types are a signpost and an eye-opener to other subjects regarding their genres.

That being stated, advertising is a kind of genre in communication events. Nonetheless, that statement is not without some contentions. Among other critics, Cook's (2001) theorisation argues that it is a great task to consider advertising as a genre. The defence of Cook is that this form of communication is unrestricted to the use of particular materials. Following Cook (2001), advertising is not a stable semiotic system because the structures are dynamic, a synthesis of many components. Such a communicative exercise is slippery, colonising other territories without a check. By implication, advertising seeks and deploys any mode that has the strength to persuade people to consumption.

The inkling of considering advertising as a genre generates some impulses. For Vestergaard and Schroeder (1985), advertising is a sub-literary genre that uses verbal and visual art to convince the target audience. That genre spirit influences Myers (1994) to submit that advertising is a semiotic genre with typical practices, as constructed in the manner that persuasive business works. In addition to that, Forceville (1996) asserts that advertising demonstrates a textgenre, which has a clear intention of inspiring readers to patronise goods and services. One might say that advertising has a class of resources characteristic of similar structural elements, performing social functions. These elements, which Kress (2011) labels as modes, are goal-oriented conventional devices that express meaning potentials. Gieszinger reveals that

The existence of the word, advertisement, in everyday vocabulary also implies that there is a text-type, advertisement. However, language users are aware of a class of text called advertisement and often have a fixed attitude towards advertisements. (Gieszinger 2001: 15)

Drawing on the various perspectives advertising has common features of fabrication qualities, structural considerations, modal disseminations, and semantic values. It is also characteristic that people generally have particular behaviours towards advertising. Social actors consider the communication as a disturbingly nauseating entity. The semiotic configuration of advertisements (henceforth: ads), one might attest, positions the communication as a genre and register, as discussed latter. In most advertising systems, there is a usual 
interplay of the image with the linguistic element and the colour scheme, offering semiosis (meaning of modes) to readers.

The concept of genre is a relevant point in humanities and social sciences. This rallying theme has attracted scholars such as Swales (1990), Bhatia (1993, 2008), Hyland (2004, 2012), Dewitt (2008, 2009), and Hiippala (2014) to discuss genre in terms of the academic setting, professional practice, social interaction, multimodal enquiry, and critical awareness. There are studies on historical research (Bawarshi \& Jo Reiff 2010), multi-genre (Guo-wei 2010), web genres (Cambria, Arizzi \& Coccetta 2012), film with GeM basis (Bateman 2013), writing across contexts (Yancey et al. 2014), developing writing skills parallelism (Worden 2015), genre interpretation (Koski, Frog \& SKS 2016), and genre innovation (Tardy 2016). Though somehow confusing and challenging, systemicists of the Hallidayan school, provide ground-breaking discourses on the matter of genre as related to register (Halliday 1995, Eggins 2004, Martin \& Rose 2013, Bloor \& Bloor 2013, Thompson 2014, Dalamu 2018).

Subsequently, the present study draws inferences from the abovementioned domains in order to establish that advertising is a semiotic genre in multimodal discourse. In order words, this study discusses advertising as a genre (Baldry \& Thibault 2006), by analysing the consistent interplay of images and written modes as the semiotic resources interact in a copresence to generate meaning potentials. The adaptation of Halliday's dialogic interacts - speech functions (Halliday \& Matthiessen 2014) into Kress and van Leeuwen's (2006) communicative acts (van Leeuwen 2005) assist in exploring meaning from the ads. Thus, the questions below have assisted in elucidating the interplay of images and words in advertising communications.

- What are the relationships of modes in the advertising systems?

- How has the communicator culturally deployed modes to inspire viewers?

- What roles have the cumulative dialogue of the written modes played in the communications?

- At what frequency has each written semiotics function recurred in the ads?

\section{MAIN SECTION}

\subsection{Literature Review}

\subsubsection{Genre vs. Register: A Contextual Equation}

The notion of habitualisation appears to provide a platform for the release, evolvement, growth, and development of genre. Habitualisation, in Berger and Luckmann's (1966) sense, points to the implementation of a certain activity in a repeated form. The replication qualifies someone else, following the same guidelines, to perform such an exercise in the same way, in different places, and in different period of time. That reprise stimulates Berger and Luckmann (1966) 
to add that all human enterprises are activities of habitualisation. The researcher might suggest that most human actions are activate-able in future time the way such actions have been performed in the earlier time, using the same processes and methods. In that respect, Eggins (2004) pinpoints habitualisation as a quintessence of standards that saves people's time and energy, eradicating challenges from human activities that might have ordinarily been a causality of frustrations. The economic values, engineered by the subject template, create psychological reliefs for people in its general nous.

The merit of habitualisation, as mentioned earlier, sparks the insight of genre that drives the function of language and its forms within a linguistic community, contributing to the semiotic register of language. Martin (2009) understands that stricture to remark that genre is a staged goal-oriented activity, engaging the members of a cultural community; whereas Halliday and Hasan (1985: 108) reveal that "a genre is known by the meaning associated with it ...; genre is a short form for the ... elaborate phrase genre-specific semantic potential". Drawing on the arguments above, genre is a pictorial communication that is culturally oriented, focusing on a specific meaning potential. Genre's structural and semantic treasures operate within an individualised community. As a social activity, encircled with a contextual configuration, equivalent to habitualisation, genre delimits discourses, enhances creativity, and balances one's knowledge of a course in order to create specialisation that invariably leads to development (Bhatia 2002, Hyland 2007). Such a recurring situation could also construct adequate meaning potential in interpersonal communication.

As illustrated in Figure 1, the probable eminent promoters of genre in linguistics are systemicists. Most linguists tend not to discuss genre, owing to the confusion that emanates between it and register (Crystal 1991, Gieszinger 2001, Ravelli 2019). Register is a supposed linguistic category as such is concerned with a specific given text, related to its structural forms, phonological constructions, and substantial characteristics, compared to a similar text in a particular environment.

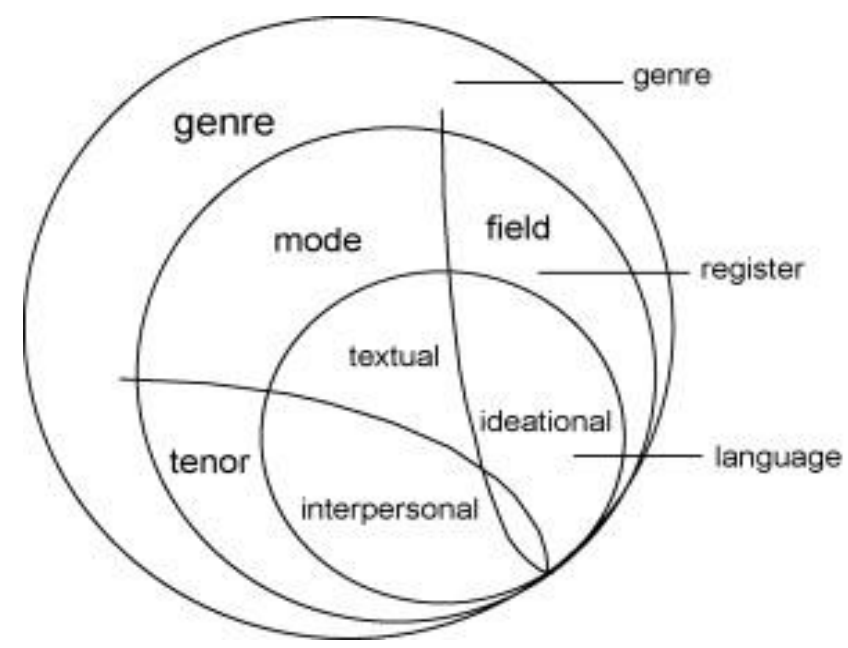

FIGURE 1. Genre in SFL (Martin 2009) 
By implication, register is a system of situational features related to a context, which could offer the audience the basis for exploring its semiotic properties (Bateman 2008). As it were, register is a configuration of semiotic resources, which recurs in the same pattern in another semiotic system, bounded in cultural importance. This seems to project register as an open-ended system where semiotic modes converge to generate meaning potentials. It then holds that genre and register are seemingly two entities of a kind, hypothesising a degree of confusion, indebted to the functional and cultural overlaps experienced in the terminologies. For Halliday, as Leckie-Tarry (1993) remarks, genre is a lower order semiotic concept; whereas register is the higher order, subsuming genre. As shown in Figure 1, Field, Tenor and Mode are elements of register, which also determine the interpretation of the components and meanings of genre (Lee 2001; Martin \& Rose 2009; Bateman, Wildfeuer \& Hiipala 2017; Nwinlaaru 2021). In a simple term, genre accommodates the context of culture; register epitomises the context of situation.

Genre, being the investigative province of the present study, focuses on the textual structures and environment of ads as to identify, analyse, and explain their semiotic resources in copresence. This is to understand how the modes are inclined to cultural feet of social actors. That suggests the great role that the culture of interactants plays in the choice of the designer's modes. This influence positions genre as a purposeful communicative enterprise with certain constraints, being an ensemble of modal affordances. In corollary, a member of a cultural jurisdiction is at advantage to understand a genre better than individual aliens to a community. As a conventional disciplinary article, genre is interdisciplinary, typifying a cross-semiotic framework. Perhaps such features inspire Van Leeuwen (2005), and Bateman, Henschel, and Delin (n.d.) to argue that genre is generally employed to reflect a type of text. That seems typical in the recognition of similar characteristics in two, three, and more texts with similar operational perceptibility, descriptions, and semiotic habits of content, form, and function. Thus, social semiotic approach to genre focuses on the function of modes in any social environment, such as the advertising system.

\subsubsection{Conceptual Framework}

The insight of Multimodal Communicative Acts appears as the synopsis of speech acts theory and acts of dialogue. Its application in this study has the capacity to elucidate the nature of the written modes, in terms of frequency, rank analysis, and context. Multimodal Communicative Acts will also indicate the relationships, existing among the modes of the semiotic systems. Speech acts theory is a conceptualisation of Austin (1962), where the theoretician situates a mode of communication in language within the purview of a locutionary act, illocutionary act, and perlocutionary act. Locutionary and illocutionary acts connect the speaker; perlocutionary act focuses on the effect of a piece of 
information on the audience. This perspective stimulates Halliday (1995) to construct the speech functional roles as being a form of dialogue substantial as interact. Interact, in Halliday's (1995) point of view, is a sort of exchange between interlocutors, regarding giving and demanding. Van Leeuwen (2005) maintains that giving entails receiving; demanding indicates giving in response.

Interact is a label from the interpersonal Metafunction, where giving and demanding relate to information and goods-and-services. As a result, an interlocutor could: give information; demand information; give goods-andservices; and demand goods-and-services (Thompson 2014). These four spheres, in Halliday and Matthiessen's (2014) manifestation, are semiotic-semantic reconstructions of statement, question, offer, and command. These linguistic elements operate within the basic patterns of declarative, interrogative and imperative clauses (Dalamu 2019a). Some structures that function as offer are declarative substances that display modality affairs as: I would go to Canada this year; Wale might be around soon; and Yemi should love his brother. Some of the other mood systems of the interpersonal Metafunction are: I am a great man; Where are you going?; and Rise up to the challenges of life (Bloor \& Bloor 2013).

Multimodality is a field that considers meaning-making utmost from modes in copresence of a semiotic space. Some of the modes, for instance in ads, are pictures, words, and colours. The ensemble of modes in meaning-making enterprises motivates van Leeuwen (2005) to consider a form of interaction in a semiotic system as being an act, giving rise to the concept of "Multimodal Communicative Acts". The notion of communicative acts is an extension of SFL's speech functional resources to explain images (Kress \& van Leeuwen 2006), with a view that the image, as operational in the grammar of language, also gives and demands something from viewers. Moreover, images are interactants of a semiotic system, as designers organise and employ modes to do things in terms of persuasion, instruction, explanation, conviction, and sometimes warning. As adapted from Van Leeuwen (2005), Figure 2 demonstrates a harmony of concepts that realise "Multimodal Communicative Acts". 


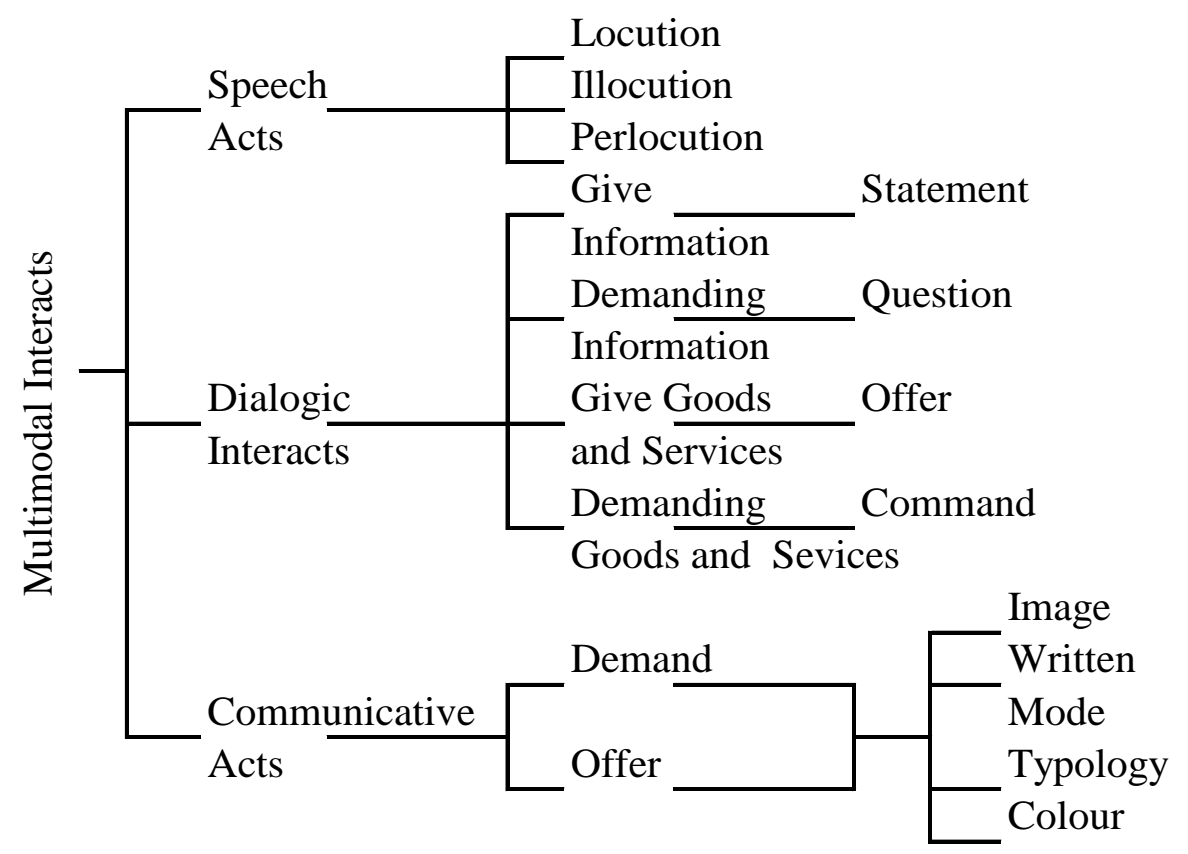

FIGURE 2. A system of multimodal interacts (van Leeuwen 2005: 117-121)

Demand and offer in communicative acts involve two kinds of participants. Following Jaworski and Coupland (2006), there are represented participants and interactive participants. The former is the images, while the latter depicts the social actors involved in a semiotic configuration - the designer and the viewer. It is worth stressing that represented participants and interactive participants engage in three forms of relationships. These are: relationships of represented participants (mode + mode), relationships of represented participant and interactive participants (mode + designer + viewer); and relationships of interactive participants (producer + reader). It happens that when represented participants look straight at the viewer, vectors form the participants' eyelines, connecting the participants with the viewer in order to establish a contact (Kress $\&$ van Leeuwen 2021). These relations result into the communicative acts of direct address (e.g., gaze and gesture) and indirect address (e.g., no contact, emotional freedom, and freedom from subjectivity).

\subsection{Methodology}

The goal of this study, to exemplify the interaction of images and words in a similar semiotic copresence to generate meaning, informed the collection of relevant ads from The Punch Newspaper, the Internet, and advertising signposts in the streets of Lagos, Nigeria. Lagos, being the major commercial centre stemmed the decision of making the city a data collection site (Osoba 2012). The readership traffic-cum-strength and patronisation were considerable factors for harvesting ads from The Punch Newspaper and the Internet. Mrs Bonke, 36 years, supported the author in the collection process. Bonke's knowledge of 
Lagos domains was a heartening dynamic for seeking her assistance in the ads' collection development.

\subsubsection{Instruments and Design}

An hp2000 ${ }^{\circledR}$ laptop with an Airte ${ }^{\circledR}$ modem and a WB50F Samsung ${ }^{\circledR}$ camera were functional instruments of ads' collection and processes. The laptop performed two functions of downloading some ads from the Internet and the same time the regulation of all the harvested ads into required shapes and sizes. The camera only helped in capturing the ads from erected frames and pages of The Punch Newspaper. Thereafter, the analyst employed a stratified sampling procedure for selecting the ads meant for investigation (Patton 2015). The fact that the stratified sampling method saves cost and enhances a quick decision making that could represent a large number of ads informed its application. The population of the harvested ads is 32 pieces.

\subsubsection{Procedure}

Using the concepts of Population, Strata and Subject, within the cover of the sampling method, the analyst stratified the population of 32 pieces of ads into eight groups. It was from each group that an item of communication was chosen to stand as a subject (a mini-corpus). The selection of the ads anchored on the represented and interactive participants, their organisation, and the possibility of partnership to generate meaning (Maxwell 2014). The typographical appearances of the written modes also stirred the author's choice for an ad.

One could stress that Bonke collected $\$ 20,000.00$ for her personal and car maintenance when we dashed out to harvest ads ( means Naira, a symbol of the Nigerian currency). The researcher with the application of Halliday and Matthiessen's (2014) terminology of speech resources roles, employed tables and graphs to elucidate the frequencies of the grammatical components of the dialogue structures, as demonstrated in Table 2, Figures 11 and 12, latter below. Besides the quantification of linguistic devices (Dalamu 2019b), explanations on the interplay of images and wordings followed after van Leeuween's (2005) theorisation and Kress and van Leeuwen's (2006) insight of communicative acts and image acts respectively. 


\subsubsection{Presentation of Communicative Clauses}

Table 1 demonstrates the clauses of the eight ads, operational in the dialogic structures.

\begin{tabular}{|c|c|c|}
\hline Product & Ad & Dialogue Structures \\
\hline \multirow{3}{*}{ 态 } & $1 \mathrm{a}$ & Celebrating the world's no. 1 fixer \\
\hline & $1 \mathrm{~b}$ & Happy Mothers' Day to all the beautiful and inspiring women out there. \\
\hline & $1 \mathrm{c}$ & Have you called mum today? \\
\hline \multirow{7}{*}{ 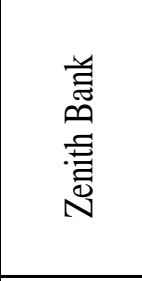 } & $2 \mathrm{a}$ & Live the good life with our Eazyloans \\
\hline & $2 b$ & You can now enjoy 30 -day loans of up to 100,000 at only $30 \%$ flat. \\
\hline & $2 \mathrm{c}$ & Simply dial *966*11\# \\
\hline & $2 \mathrm{~d}$ & Terms and conditions apply \\
\hline & $2 \mathrm{e}$ & Bank Eazy way with *966\# \\
\hline & $2 f$ & No data required \\
\hline & $2 \mathrm{~g}$ & Eazy banking \\
\hline \multirow{7}{*}{$\begin{array}{l}\text { 岂 } \\
\text { ص } \\
\text { 它 }\end{array}$} & $3 \mathrm{a}$ & Make money with GTWorld and 737 \\
\hline & $3 b$ & Turn our banking channels into your perfect hustle tools \\
\hline & $3 c$ & Simply help people send money \\
\hline & $3 d$ & Buy air time \\
\hline & $3 e$ & And pay bills \\
\hline & $3 f$ & And earn commissions \\
\hline & $3 g$ & While you are at it \\
\hline \multirow{8}{*}{ 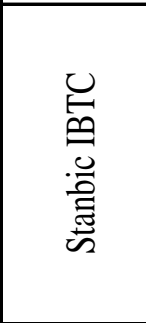 } & $4 \mathrm{a}$ & Pleasant surprises \\
\hline & $4 \mathrm{~b}$ & It can be \\
\hline & $4 \mathrm{c}$ & We thank you for your support in the course of a challenging year \\
\hline & $4 \mathrm{~d}$ & May this season bring restoration, peace and prosperity. \\
\hline & $4 \mathrm{e}$ & Merry Christmas \\
\hline & $4 \mathrm{f}$ & And have a New Year filled with possibilities \\
\hline & $4 \mathrm{~g}$ & Stanbic IBTC, a member of Standard Bank Group \\
\hline & $4 \mathrm{~h}$ & It can be \\
\hline \multirow{4}{*}{ 离 } & $5 \mathrm{a}$ & Airtel the smartphone network \\
\hline & $5 b$ & Airtel the smartphone network \\
\hline & $5 c$ & Join us on the network with... \\
\hline & $5 d$ & The widest 4G Lite coverage in Nigeria \\
\hline \multirow{7}{*}{ 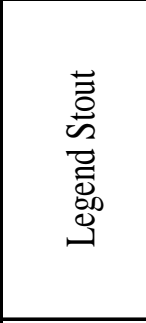 } & $6 \mathrm{a}$ & What's real brewed stout? \\
\hline & $6 \mathrm{~b}$ & It's what you get \\
\hline & $6 \mathrm{c}$ & $\begin{array}{l}\text { When real stout ingredients are full brewed under the highest standards, } \\
\text { through unique process }\end{array}$ \\
\hline & $6 \mathrm{~d}$ & That gives it a unique taste, fuller body and richer foam head \\
\hline & $6 \mathrm{e}$ & Every ounce of Legend Extra Stout goes through this full brewing process \\
\hline & 6f & Giving every sip the credibility to be called 'the real deal' \\
\hline & $6 \mathrm{~g}$ & Legend, the real deal \\
\hline \multirow{2}{*}{ 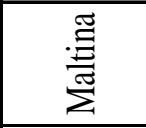 } & $7 \mathrm{a}$ & Enjoy complete richness of Maltina \\
\hline & $7 \mathrm{~b}$ & Nourishment for life \\
\hline \multirow{8}{*}{ 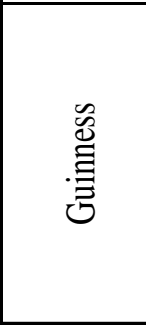 } & $8 \mathrm{a}$ & $17: 59$ \\
\hline & $8 \mathrm{~b}$ & Welcome to Guinness time \\
\hline & $8 \mathrm{c}$ & Over 100 million worth of airtime to be won \\
\hline & $8 \mathrm{~d}$ & To win, text code under your crown cork to $17: 59$ \\
\hline & $8 \mathrm{e}$ & Terms and conditions apply \\
\hline & $8 f$ & Drink responsibly \\
\hline & $8 \mathrm{~g}$ & www.drinkiq.com \\
\hline & $8 \mathrm{~h}$ & Guinness made of more \\
\hline
\end{tabular}

TABLE 1. Clauses of the analysed ads 
The elements in Table 1 are the written modes in the analysed ads. Their appearances represent the manner at which the advertisers deployed them in the semiotic systems to generate meaning potential(s). The analysis of these clauses, in the form of dialogic interacts, shown in Figure 2, are featured from Figure 3 to Figure 10.

\section{DISCUSSION AND ANALYSIS}

The modes of the advertising system naturally interact in order to generate meaning. The meaning production is as a result of the interplay of elements such as images, wordings, and colours, functional in a specific copresence. It is in that regard that cultural treasures of the interactive participants (meaners and viewers) play great roles in deducing meaning potentials. The exchange of the individual mode potentials, drawing on Halliday and Matthiessen's (2014) conceptual gradients, is in the spheres of give information, demand information, give goods-\&-services, and demand goods-\&-services (Dalamu 2019c). The construct refers that represented participants (communicative modes) and interactive participants (designers and readers) are involved in dialogic interactions, communicating meaning to persuade readers. In addition, the deployment of van Leeuwen's (2005) dais, and Kress and van Leeuwen's (2006) procedures on image communicative acts assist to elucidate some meaning potentials of modes, interplaying in the semiotic configuration of ads in the form of 'demand' and 'offer'.

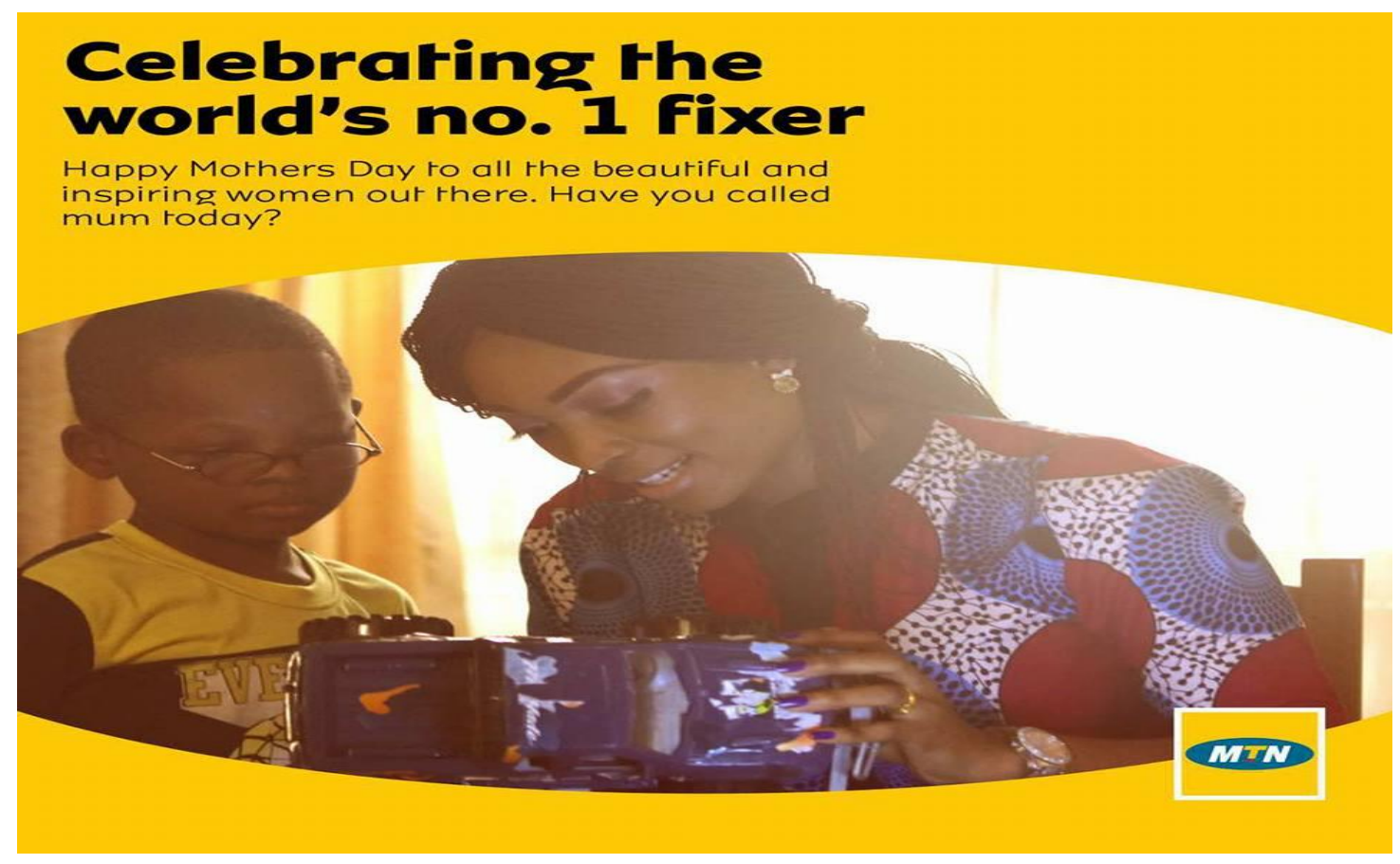

Ad 1 


$$
\text { 1a Celebrating the world's no.1 fixer }
$$

1c Have you called mum today? Demand information
$1 \mathrm{~b}$

\begin{tabular}{|l|}
\hline Happy Mother's Day to all the beautiful \\
and inspiring women out there \\
\hline Minor clause \\
\hline
\end{tabular}

FIGURE 3. MTN ad dialogue structure analysis

Ad 1 displays three images of represented participants. These are: a woman, a boy, and a toy car. The woman, supposedly, a mother, touches a toy car explaining some details to the child, as indicated through the gaze of her eyes (examining the toy) and her mouth (opening up as being talking about something). The woman's gaze tends to influence the child, wearing a pair of glasses, to consider following the manner of the mother. The child (perhaps a boy) looks also at the toy. Observations show the influence of the mother on the child. It is quite unclear the things that the mother is examining from the car, as the toy lies on an item with its side. The copresence of the represented participants demonstrates a form of social power that the woman has over the child.

The communicator acknowledges such power to consider women as the world's no. 1 fixer. As a result, Celebrating the world's no. 1 fixer reveals to viewers that the woman, as a represented participant, is repairing the toy automobile for the child's use. The punctuated structure exalts the mother as a great entity in the human race. By implication, the designer points out that the woman is the core of the family; when a family is managed well other things that necessitate growths and developments of society will naturally fall in place. If not for that the designer has deleted the components, MTN is, from the structure, a whole information offered could have been [MTN is] celebrating the world's no. 1 fixer.

The minor clause, Happy Mother's Day to all beautiful and inspiring women out there, exhibits the mission of the ad to readers. The aim is to honour women all over the world for the indispensable and unquantifiable roles that individuals play in all walks of life. Apart from the boldness and hugeness of the structures in Ad1a, lexemes such as beautiful and inspiring eulogise the womanhood. Beautiful refers to women as being possessors of pleasantly charming exteriors. However, the communicator goes ahead to utilise the word, inspiring, to locate additional characteristic of the woman folk. That is, every woman ought to communicate to people a supernatural stimulus, enlivening good ideas. Then, it is not pretty fair enough to be attractive, cute, and gorgeous; stylishly perfect appearances of women cannot give the society what it demands. Rather, as the publicist attests, the womanhood should be excellently exceptional and greatly marvellous in managing matters in all spheres.

That claim suggests that the $\mathrm{MTN}^{\circledR}$ ad focuses on lovely women of great skills and potentials, impacting usefully cerebral knowledge in society. A 
consideration of the woman dignity informs the interactant to ask a question: Have you called mum today? The calling of mum is to show appreciation to the endeavours that the mother has made to develop our society. The meaner employs world's no. 1 fixer, mothers, women, and mum as cohesive decorations on the image of the woman in the ad. In summary, the communicator conveys motherhood attributes, using the contributions of women in society to sensitise readers into consumption of MTN services, wisely remarking that anyone who cares for and regard women as the ultimate must offer great love and repute for MTN products. The yellow colour expresses a kind of joy and rational stimulation for the advertised product (Chiazzari 1998).

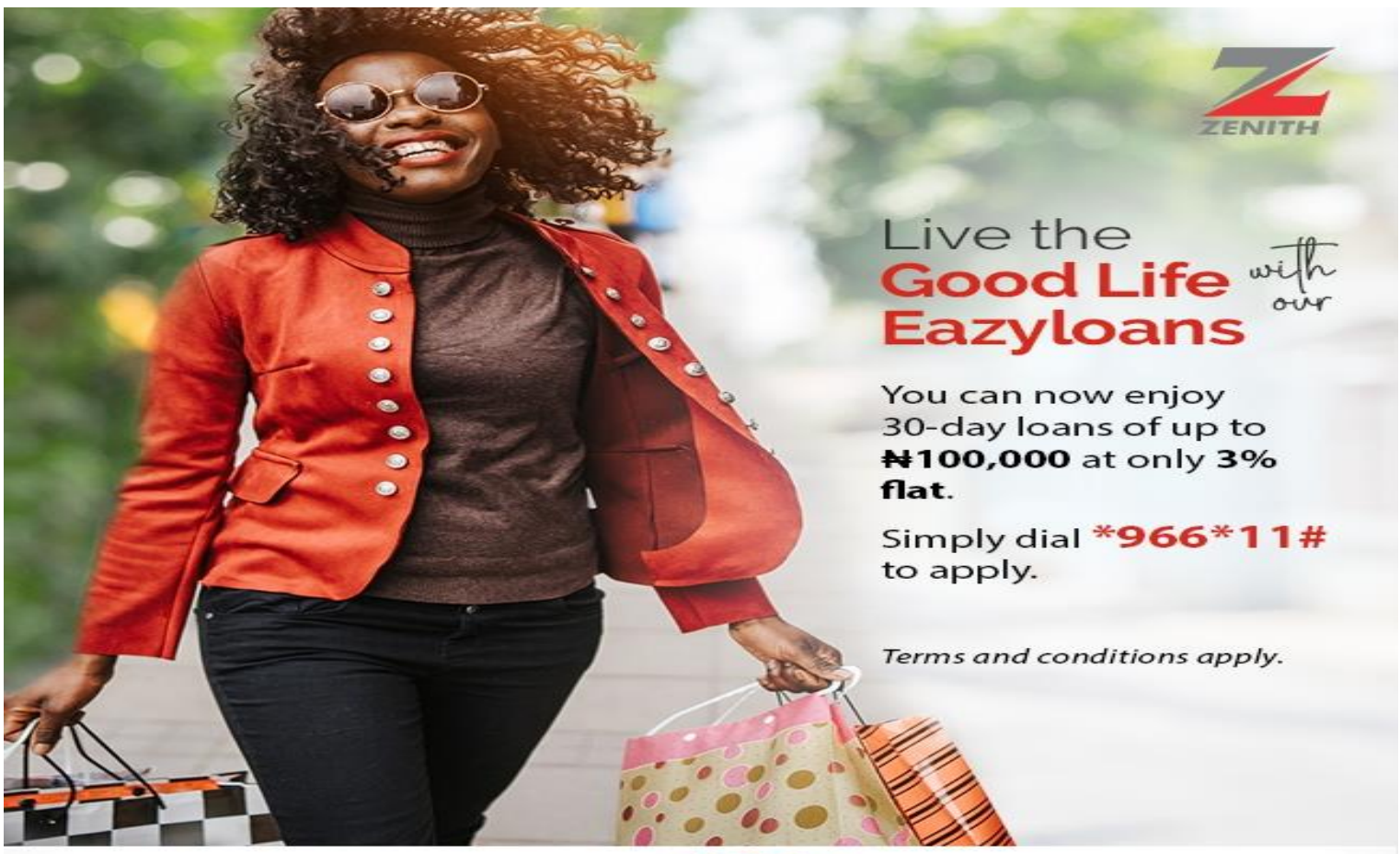

Bank the Eazy way with * 966 \# No Data Required!

Ad 2

2a $\quad$ Live the good life with our Eazyloans

$2 b \quad$ You can now enjoy 30-day loans of up to $\$ 100,000$ at only $30 \%$ flat

Give goods-\&-services

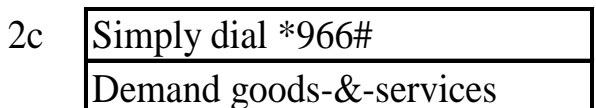

$2 \mathrm{e}$
$2 \mathrm{~d}$

\begin{tabular}{|l|}
\hline Terms and conditions apply \\
\hline Give information \\
\hline
\end{tabular}

$2 \mathrm{~g}$

\begin{tabular}{|l|}
\hline Eazy banking \\
\hline Give information \\
\hline
\end{tabular}

FIGURE 4. Zenith bank ad dialogue structures analysis 
There are animate and inanimate objects, functioning as represented participants in Ad 2. These are a happily enthusiastic lady and some bags. The appealing lady holds the bags (of about four) in her hands; two bags in the left hand and right hand respectively. The handles of the bags are connector, creating cohesion between the joyful lady and a set of bags in both sides. The pictures show that the bags are full of products from the market (Forceville 2020). That is the reason that the bags are not flappy. The young woman is laughing. The liveliness is a probable cause of the flowing of her hairdo. The happily marvellous lady appears to be walking with a fashionable sunshade. One would not have understood many things from the appearance, except that the designer stimulates readers with the Halliday's concept of demanding goods-\&-services of Live the good life with our Eazyloans (Halliday \& Matthiessen 2014). The compound word, Eazyloans, discloses the reason for the lady's current form.

Thus, it is Eazyloan that facilitates the present exposition of the lady, presenting her noble being to viewers. Zenith's Eazyloan is an initiator of good life for interested individuals. One of the interactive participants, the meaner, describes the duration, the amount, and the interest of the loan to be 30-day loans, $\# 100,000$, and $30 \%$ flat. The statement incites readers to immediately pursue to process the loan. The designer further wheedles the other interactive participant, the viewer, intimating such an individual with the channel of processing the loan, commenting that: Simply dial ${ }^{*} 966^{*} 11 \#$ to apply. Dial pinpoints a selection of this code, ${ }^{*} 966^{*} 11 \#$, in order to gain access into the application tenets of Eazyloans. To optimise the process, placing the application in a fast track, applicant-customers must satisfy to meet some requirements. Those terms spark the deployment of the statement, Terms and conditions apply.

There are some striking phenomena that the designer employs to fascinate readers, which are the red typographic modes, as reflected in the half part of the Zenith ${ }^{\circledR} \operatorname{logo}, Z$, Good Life, ${ }^{*} 966^{*} 11 \#$, and ${ }^{*} 966 \#$. These are emphases representing the Zenith Bank traditional colour. The colour scheme emphasis predicates on Good Life and *966\# in order to demonstrate the influence of Zenith on these items, making Zenith to be responsible for the devices. In other words, good life, Eazyloans, and ${ }^{*} 966 \#$ are marketing mechanisms of Zenith. That is the motivation behind the repetition of *966\# two times, the deployment of Eazy three times, and interchanging the word $s$ in easy for $z$. $Z$ is this linguistic communicative context connotes Zenith. As the use of ${ }^{*} 966 \#$ in financial transactions engenders Eazybanking, so also has red symbolises passion, courage, and power (Engelbrecht 2003) in this communication. 


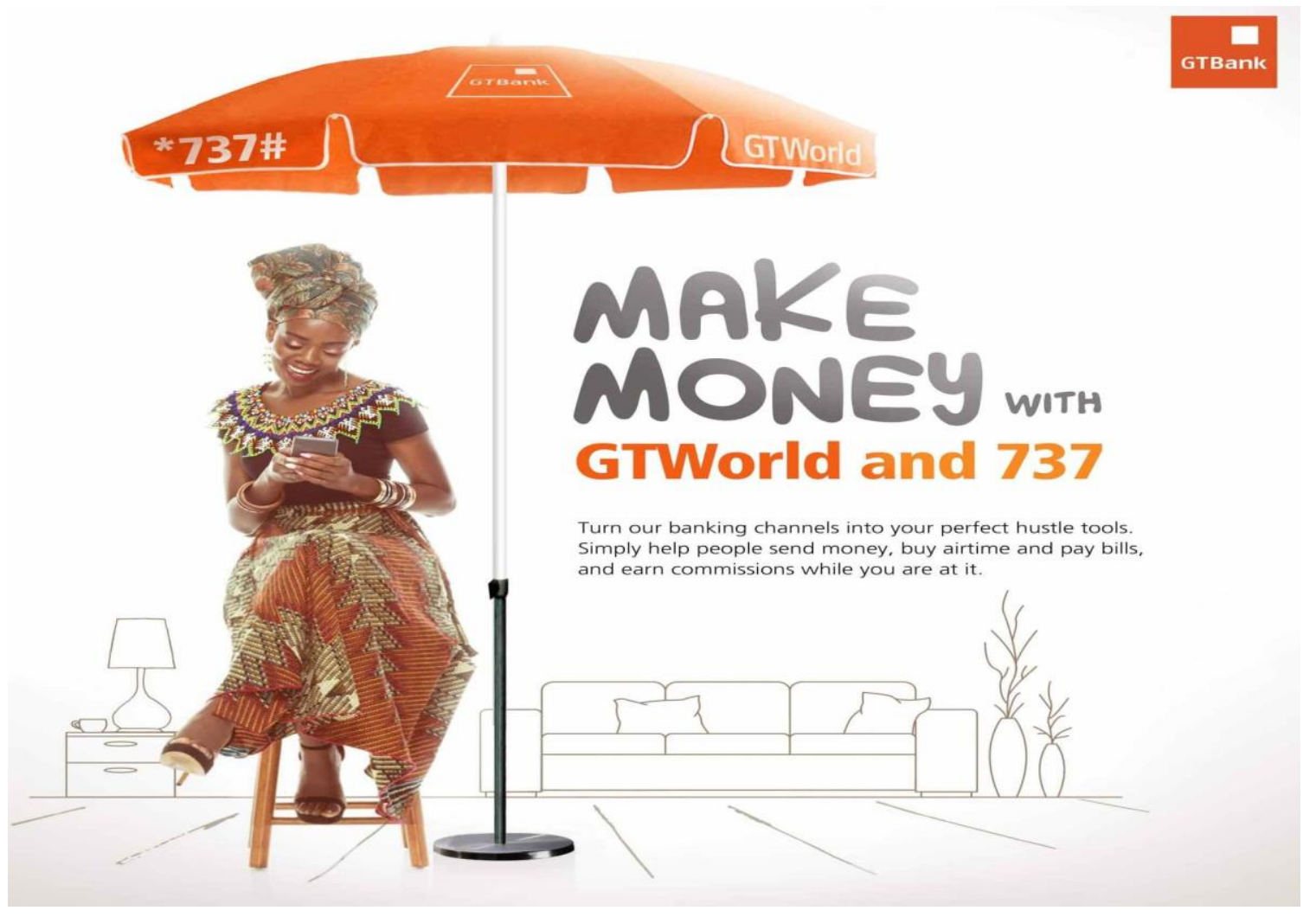

Ad 3

$3 a$

\begin{tabular}{|l|}
\hline Make money with GTWorld and 737 \\
\hline Demand goods-\&-services \\
\hline
\end{tabular}

3b Turn our banking channels into your perfect hustle tools Demand goods_\&-services

\begin{tabular}{ll|}
$3 c \quad$ Simply help people send money \\
\hline Demand goods-\&-services \\
\hline
\end{tabular}

$3 d \quad$ Buy airtime Demand goods- $\&$-services
$3 \mathrm{e}$

\begin{tabular}{|l|}
\hline And pay bills \\
\hline Demand goods-\&-services \\
\hline
\end{tabular}

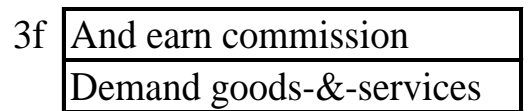

$3 \mathrm{~g}$ While you are at it Give information

FIGURE 5. GT bank ad dialogue structures analysis

The represented participants of Ad 3 are modes with different affordances. Prominent among the modes is the picture of a young woman, sitting on a stool, holding a cellphone. She dresses delightfully charismatic in a Nigerian local outfit, expressing a mood. As the young lady crosses one leg over the other, one observes a disposition of interaction between the lady and a cellphone. The human-computer mediated copresence describes the outcome of the lady's expectation, which the designer exhibits as profit making with GTWorld and 737. It means that anyone who buys into the idea of considering GTWorld and 737 as 
an avenue of perfect hustle tools will not only receive favour and fortune; the individual will have peace, comfort, and luck.

The long-standing umbrella typifies the domain of money-making, a business available for all. Consequently, the interested personality in GTWorld and 737 does not need a shop or an expensive office to achieve a dream, the wide umbrella, as the ad projects, is the major panacea of the propagated banking business. The images of a drawer, a table lamp, a sofa, and, the flower bottles are seemingly the imaginary equipment that the young lady intends to use the supposed generated profit for. The meaner tells the other social actors that GTWorld and 737 are hustle tools, which help people to become an entrepreneur. In that sense, an individual, who obtains GTWorld and 737 products, will have the capacity to: send money, buy airtime, and pay bills. These operations have made the users of GTWorld and 737 agents of $\mathrm{GTB}^{\circledR}$. The position motivates the advertising practitioner to attest that people will earn commissions while one is successfully consistently carrying out the highlighted functions. As the designer has interchanged the young lady for the consumer (Williamson 2002), an individual, loyal to the advertised products, will possess the mindset of the lady, benefitting greatly in/from the material world.

Among all the 'interacts' in Ad 3, only 3g gives information to readers. This is because $3 \mathrm{~g}$ is a statement of an indicative clause, while the other structures are imperative clauses, compelling social actors to behave in a certain way and not another. Regarding the colour scheme, orange dominates all the other colours in the semiotic configuration. This analyst observes orange as the colour of GTBank logo, the umbrella, and GTWorld and 737. In essence, orange creates interconnections of identity in the advertising discourse. The colour, playing a prevalent role, manifests financial security, opportunity-cum-creativity, and extraordinary happiness (Heller 2009) for viewers. 


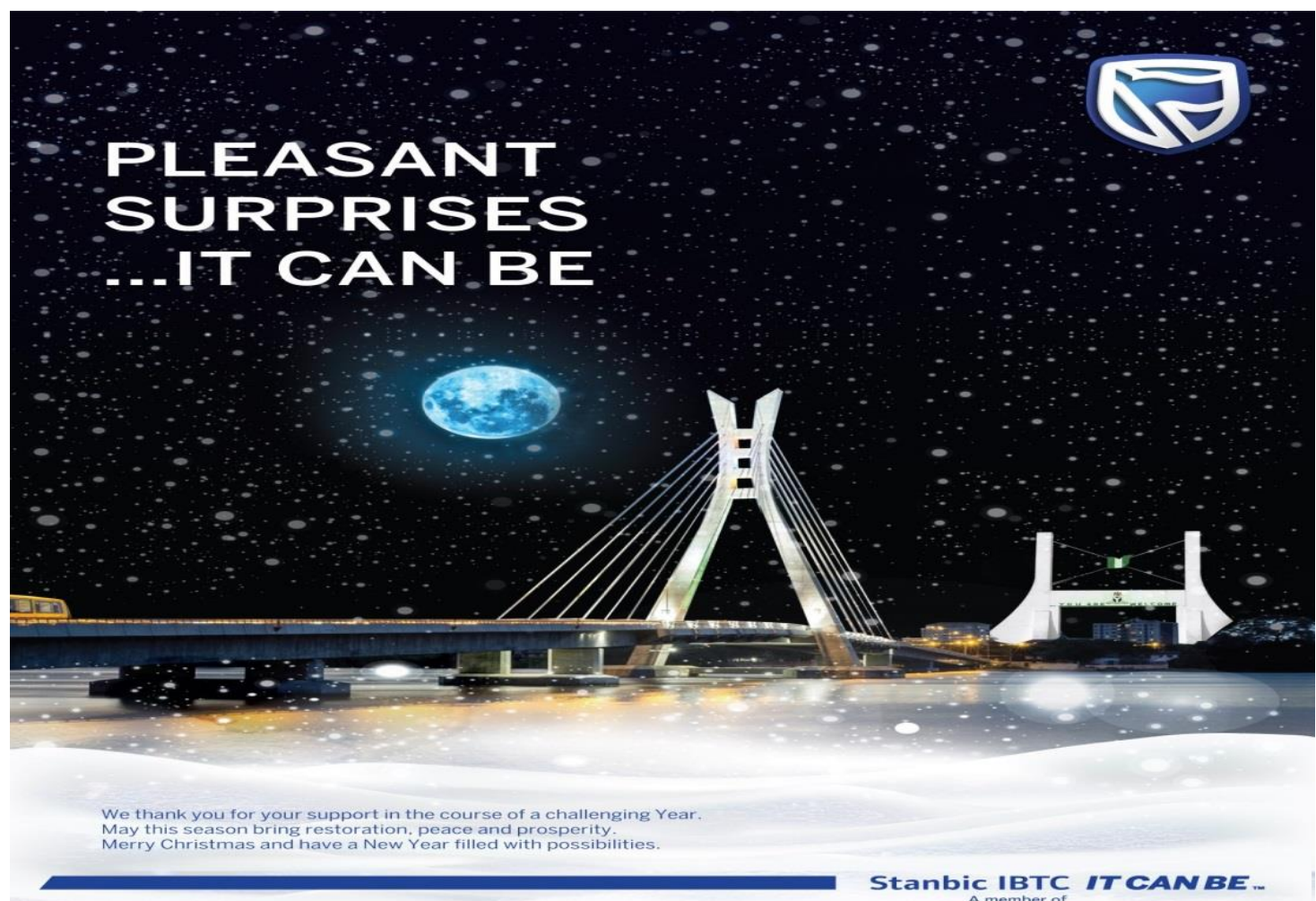

Standard Bank Group

Ad 4

$4 a$

\begin{tabular}{|l|}
\hline Pleasant surprises \\
\hline Give information \\
\hline
\end{tabular}

$4 \mathrm{~b}$ It can be

$4 c$ We thank you for your support in the course of a challenging year Give information

\begin{tabular}{|l|}
\hline May this season bring you restoration, peace and prosperity \\
\hline Give goods-\&-services \\
\hline
\end{tabular}

$4 \mathrm{e}$

\begin{tabular}{|l|}
\hline Merry Christmas \\
\hline Minor clause \\
\hline
\end{tabular}

4f And have a New Year filled with possibilities Demand goods- $\&$-services

$4 \mathrm{~g}$ Stanbic IBTC, a member of Standar Bank Group \begin{tabular}{l|l|}
\hline It can be \\
\hline Give goods- $\&$-services \\
\hline
\end{tabular}

FIGURE 6. Stanbic IBTC bank ad dialogue structures analysis

The represented participants in Ad 4 are of three domains of the sky, Lagos and Abuja. There are no doubts that the sky covers the Lagos metropolis and Abuja city at the same time. It is thus imperative to mention that the communicator constructs these objects for a reason of meaning-making. Beginning from the left, on the one hand, there is a bridge on top of the waterway, known as the Lekki-Ikoyi bridge in Lagos. The bridge is about nine metre headroom above the water level with a length of 1.36 kilometres ( 0.85 mile), as 
located in Lekki Phase 1. The architectural design on top, in a seemingly form of eks (x), signals a difference and spectacular feature of the bridge when compared to other bridges in Lagos State. This is the first cable-stayed bridge in West Africa, signifying Lagos as a landmark and hallmark of buoyant financial possibilities.

On the other hand, the next structural sign near the right side is the popular Abuja City Gate. There are facts attached to the construction of this gate. Some of these are: a sign of a shift of political power in 1991 from Lagos to Abuja; a ceremonial entrance to the new capital city of Nigeria; a sign of unity among Nigerian nationalities; a beautification pavilion of Abuja city; and a welcome signal to all visitors coming into the city. As rightly observed in Ad 4, there are two inverted arched steel-concrete blocks on each side of the edifice, connected at the middle with long steel-concrete blocks in the middle fortifying the entire structure. Significantly, there are: a metal-fabricated waved Nigerian flag, fixed with criss-crossed steel lines; the Coat of Arm of Nigeria; and a written clausal mode of YOU ARE WELCOME. One common and interesting thing about the Abuja City Gate monument and the Lekki-Ikoyi bridge is that Julius Berger constructed the two structures.

The designer chooses the two devices to depict the Nigerian commercial nerve (Lagos) and the Nigeria seat of government (Abuja). These two domains are germane to the financial sector of the economy, which Stanbic IBTC ${ }^{\circledR}$ represents. The written modes, Pleasant surprises, and ...it can be, project to readers some connotative interpretations. The bank has faced some trials in the past year, which might have shaken the business to its foundation. That is a probable reason for referencing Lagos (a business home) and Abuja (a home of power) in this semiotic system. The publication date of this ad was December, 2020 - the year that witnessed the nefarious COVID-19, the new normal, on global businesses and activities. The bold typology of the font motivates readers, inspiring individuals to good financial years ahead.

Pleasant surprises; and ...it can be are ways of assuring all the stakeholders never to lose hope on Stanbic IBTC. 2021 and beyond will undoubtedly be amazing years of financial plausibility. As a remark of encouragement, the communicator says, We thank you for your support in the course of challenging year. A prayer of assurance follows the word of reinforcement. That is, May this season bring you restoration, peace and prosperity. It is this giving of goods-\&-services (offer) that has a strong connective coherence with the image of the sunrise, being a represented participant. The sun rises in the morning to conquer darkness; comes up in tranquillity without hindrances; and shines on all things confronting encumbrances. The meaner rests on the strengths of the sun to promote Stanbic IBTC. It is on that note that the bank has a course to wish customers Merry Christmas and to have a New Year filled with possibilities. The mood system, It can be, repeated two times, as in $4 \mathrm{~b}$ and $4 \mathrm{~h}$, ardently builds confidence on viewers. The three dots behind ...it can be (4b) and the three dots in front of it can be... (4h) are symbolic modes of inciting customers to forget about the encounters of the past 
and rather to focus on the brightness of the future. The principal role of blue is an attestation to tranquillity, hope and faith (Zelanski 2003) in subsequent financial years.

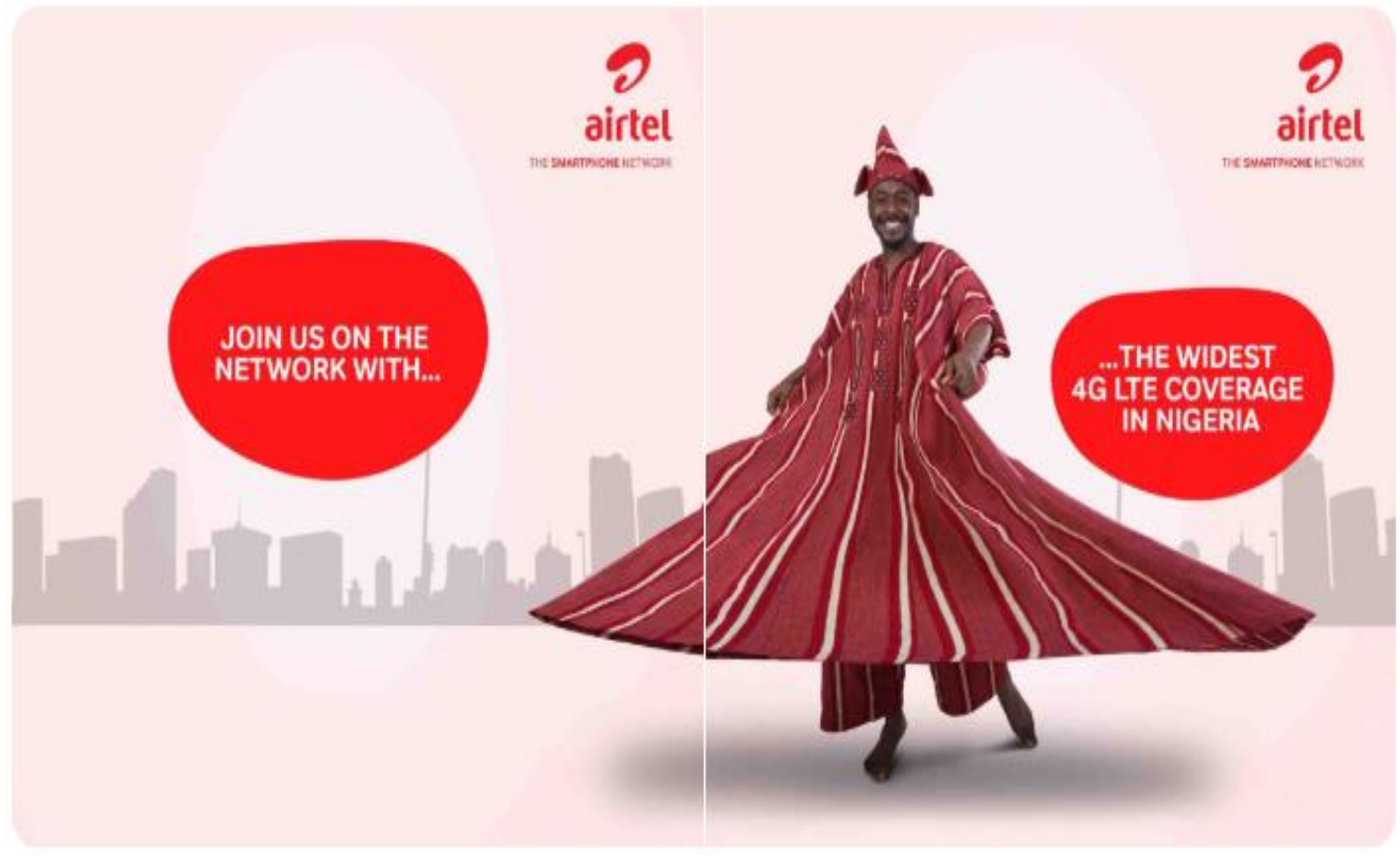

Ad 5

$5 \mathrm{a}$

\begin{tabular}{|l|}
\hline Airtel the smartphone network \\
\hline Give information \\
\hline
\end{tabular}

$5 b$

\begin{tabular}{|l|}
\hline Airtel the smartphone network \\
\hline Give information \\
\hline
\end{tabular}

$5 \mathrm{c}$

\begin{tabular}{|l|}
\hline Join us on the network with... \\
\hline Demand goods-\&-services \\
\hline
\end{tabular}

$5 d \quad$ The widest 4G Lite coverage in Nigeria Give information

FIGURE 7. Airtel ad dialogue structures analysis

Ad 5 displays a theme-rheme structure. The vertical line dividing the advertising framework into two equal parts augments this modal classification. The two segments have represented participants of a tall man standing on seashore, backing clustering images (shadows) of high-rise buildings. The appearance of the high-rise buildings influences the researcher to label the standing sphere of the tall man as being on seashore. The location of most highrise buildings in Nigeria is in Lagos Island, where most portions of the land are filled before building engineers and other experts construct meaningful but functional structures.

The image of a blissful man, who stands on his toes, is on the rhematic unit of the ad. One also observes that this individual wears a hat as he uses his two hands to hold a Yorùbá garb in his body. Such an act epitomises the convenient 
spread of the base of the dress as desired. Of course, the designer intends to convey a message to viewers. That is, the coverage of Airtel ${ }^{\circledR}$ operations are beyond a normal curve of general communication exercises. Perceptibly, the dress crosses over from the rheme back to the theme. That behaviour denotes the extent of the coverage energy of Airtel from its domain to the jurisdiction of other telecommunications operators in Nigeria. The vertical dividing line illustrates that existence.

The protrusion of the bottom of the dress from the rheme to theme is a kind of infiltration or encroachment on other communicator's territory. The designer utilises demanding goods-\&-services string to excite viewers into the Internet enterprise. As a result, Join us on the network with... the widest 4G LTE coverage in Nigeria is an invitation to readers, who are yet to understand the blaze of Airtel modem, which has been emphatically introduced two times as Airtel the smartphone network. As the communicator has employed written modes to encourage readers into patronisation of services, so has the designer deploys an element of eye contact, which Kress and van Leeuwen (2006) label as vector, to coax viewers into consumption of the advertised product. The eyes of the represented participant (the tall man) form eye-lines with that of the interactive participant (the viewer), as a means of directly persuading readers to the Airtel Internet services. Besides the laughter, the red colour schemes showcase royalty, dynamism (Kress \& van Leeuwen 2002, van Leeuwen 2011), validating the Airtel Internet's independent speed of a heightened sense and performance. The intensive nature of the Airtel smartphone network is a constraint for other operator to withstand such coverage spheres.

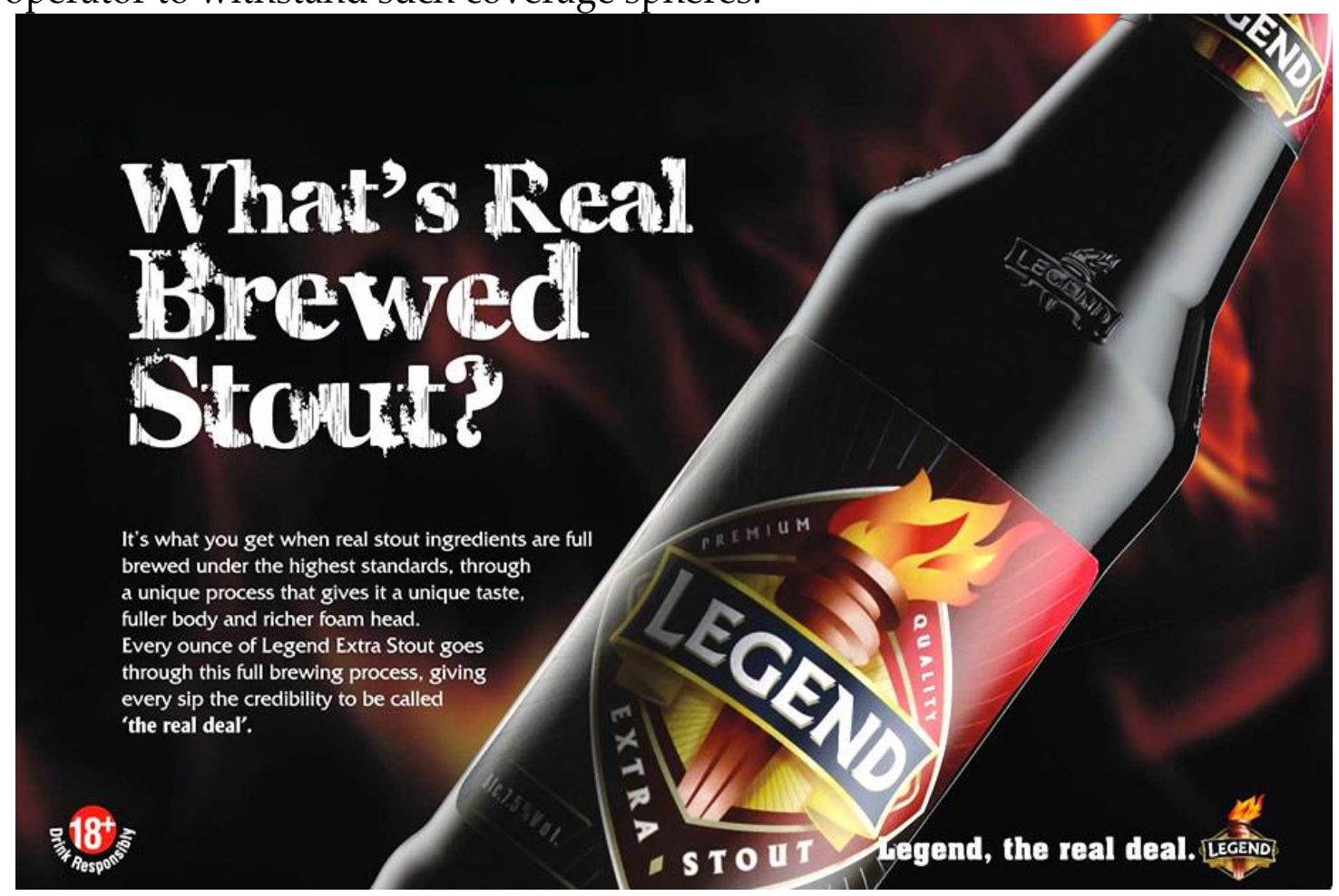

Ad 6 
$6 a$

\begin{tabular}{|l|}
\hline What's real brewed stout? \\
\hline Demand information \\
\hline
\end{tabular}

$6 \mathrm{~b}$

\begin{tabular}{|l|}
\hline It's what you get \\
\hline Give information \\
\hline
\end{tabular}

$6 c$

\begin{tabular}{l}
$\begin{array}{l}\text { When real stout ingredients are full brewed under the highest standards, } \\
\text { through unique process }\end{array}$ \\
\hline Give information \\
\hline
\end{tabular}

$6 \mathrm{~d}$

\begin{tabular}{|l|}
\hline That gives it a unique taste, fuller body and richer foam head \\
\hline Give information \\
\hline
\end{tabular}

$6 \mathrm{e}$

Every ounce of Legend Extra Stout goes through the full brewing process Give information

$6 f$

\begin{tabular}{|l|}
\hline Giving every sip the credibility to be called 'the real deal' \\
\hline Give information \\
\hline
\end{tabular}

$6 \mathrm{~g}$

\begin{tabular}{|l|}
\hline Legend, the real deal \\
\hline Give information \\
\hline
\end{tabular}

FIGURE 8. Legend stout ad dialogue structures analysis

There is one major represented participant in Ad 6. That is a mammoth bottle of Legend ${ }^{\circledR}$ stout with some signifiers in its neck and body labels. The designer places the bottle in black, diagonally at an angle less than 45 degrees, across the advertising plate. Observations pinpoint the realisation of Legend three times on the neck, shoulder, and body of the stout. Though the writing is of different typographic parameters, the repetition remains that the readers must know the main reason for the ad. The ad is about Legend; Legend alone and nothing else. This informs the outsized look and ascendancy of Legend stout on the framework. The image of the Olympic touch is on the body label, encircled with premium quality and extra stout, as indicators of the features of the alcoholic drink. One might argue that the Olympic light in the label exemplifies Legend as a kind of stout that bridges the gaps between the old and new dark ale beers, initiating peace, hope, friendliness, and tolerance among stout stakeholders.

The designer's choice regarding the written modes is to demand information. That is, What's real brewed stout? The communicator answers the question with a fragmented structure of Legend, the real deal, cancelling uncertainty and distrust. The orthographic clause, at the right bottom corner of the frame, eases the tension that What's real brewed stout creates. The motive for a quick response might be that viewers could demonstrate mixed feelings and reactions in that regard. To avoid ambiguity, misconception of thoughts, and doubts of qualities compel the publicist to swing into action, providing a rightly correct answer for readers. The typography of the fonts of the clause shows the 
importance of the written modes. The first is What's real brewed stout? (6a), and the second is Legend, the real deal (6g).

The third is sets of written modes of four clauses that offer further and appropriate information to the question, What's real brewed stout? These clauses mark Legend from three perspectives: personal benefits; production procedures; and characteristics of the stout contents. Thus, whatever enjoyment-cum-gains that an individual consumer derives from the beer is his/her lot. However, the designer protests that the satisfaction that a drinker gets from the stout anchors on the method of production, that is, the production process that the stout has undergone and the ingredients of its content. Drawing on Ad 6, the production process of Legend is unique because the beer is always being fully brewed under the highest standards.

Standards in this context points to the settings of production right from the silos to the brew house and to the packaging hall. The production machines are not only of highest standards, the brewers, engineers, and operators are also of highest standards in terms of academic qualifications and on-the-job trainings. The researcher, having observed these highlighted characteristics in the course of this investigation, might attest that those factors have given Legend a unique taste, a richer foam head, and a sipping credibility that fascinate to induce people into a consistent consumption of Legend, without a check. As the lexeme, real, repeated four times, is synonymous to Legend; so is black decorating Legend as a serious subject of dignity (Ladu 1989).

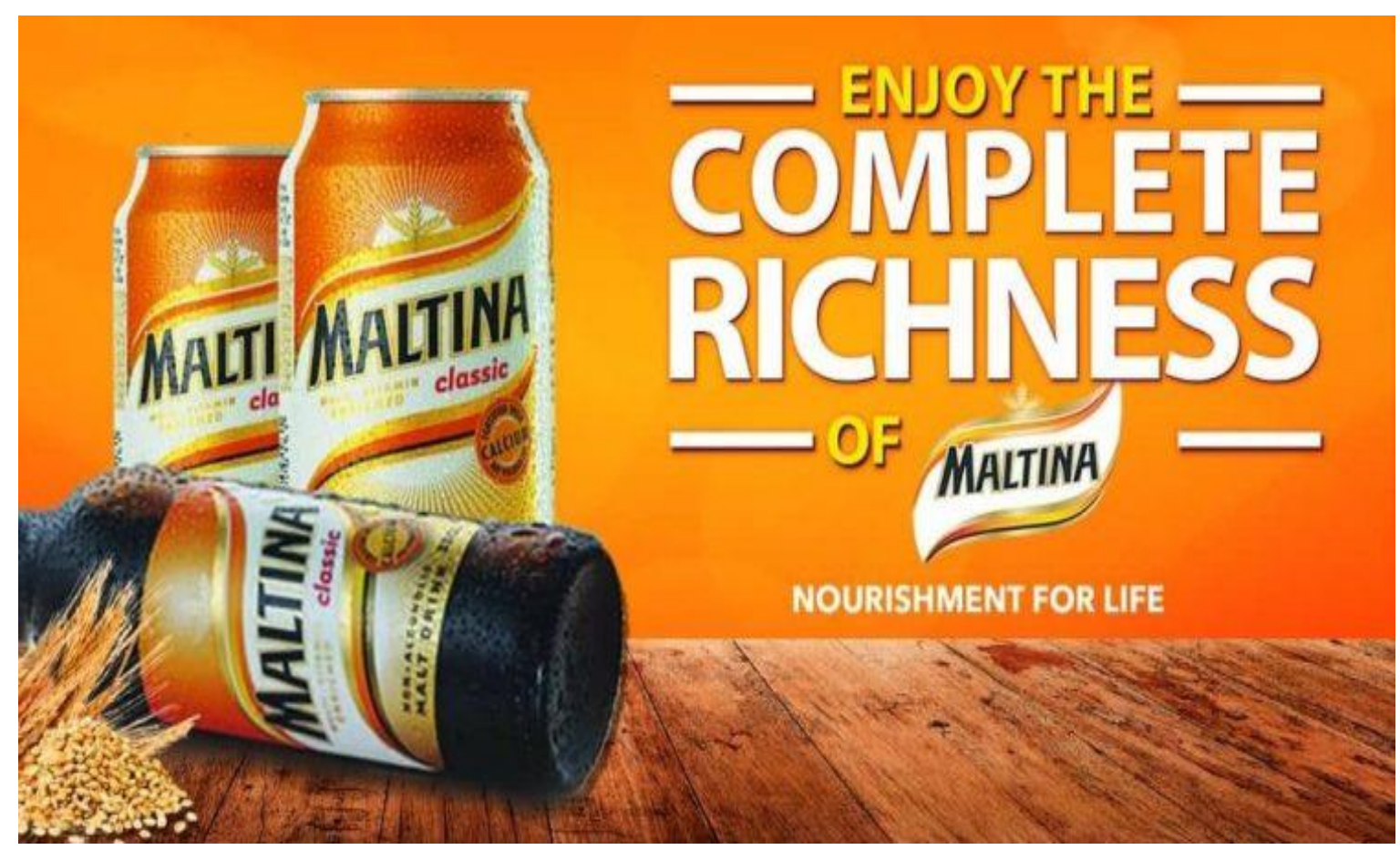


$7 \mathrm{a}$

\begin{tabular}{|l|}
\hline Enjoy complete richness of Maltina \\
\hline Demand goods-\&-services \\
\hline
\end{tabular}

$7 b$

\begin{tabular}{|l|}
\hline Nourishment for life \\
\hline Give information \\
\hline
\end{tabular}

FIGURE 9. Maltina ad dialogue structures analysis

The represented participants in Ad 7 are: two cans and one bottle of Maltina ${ }^{\circledR}$, barley straws, and a small pyramid of barley-like cereal. As the two cans are standing upright, the bottle of Maltina lies horizontally on a wood-like structure. The designer inscribes Maltina Classic on the three containers such that Maltina is bolder than Classic. The inscription shows that Classic is less important when compared with Maltina. Nonetheless, Classic, as a lexeme, supports Maltina in an underlying level of meaning. Classic points to a long-lasting perfect style of an artistic work or a sporting event. People, sometimes, connect Classic to Ancient Greece and Ancient Roman literature. In a simple term, Classic tends to modify Maltina as a product parallel to a super craft of the Ancient periods.

As the cans and bottle reveal the packaging of Maltina, the designer illustrates the content with its raw material of barley. The idea is to reveal to viewers the quality of the raw material that contributes to the production of the product. Malted barley, as one might remark, is a kind of strong cereal with a biological name of genus hordeum. The wooden material in the ad functions as a platform for showing the malt to the market, putting the cans and bottle on the floor might not speak well. Moreover, the Maltina containers demonstrate some watery spots in the bodies, explaining that the products are already iced; and must be consumed in a cold state. The wet bodies also appear to entice consumers in order to express thirst, which Maltina could quench in no time.

The designer deploys the written modes, Enjoy the complete richness of Maltina, to manifest the intention of the communication to target audience. The imperative clause demands goods-\&-services from readers, commanding individuals to purchase and drink the malt product. The pleasure derivable from the consumption of Maltina is the selling point here, which the communicator also considers as complete richness. That refers to a situation inspiring consumers to enjoy the wholeness and intense flavour of the product in order to fulfil abundant satisfactory needs or desires. There are colour schemes such as brown, white, yellow, and seemingly light brown in the configuration. Nevertheless, orange proves to be superior, positioning Maltina as a stimulant of happiness. That might be the reason for deploying the splintered mode of Nourishment for life, as everyone loves to be glad and not just for a moment, but forever. 


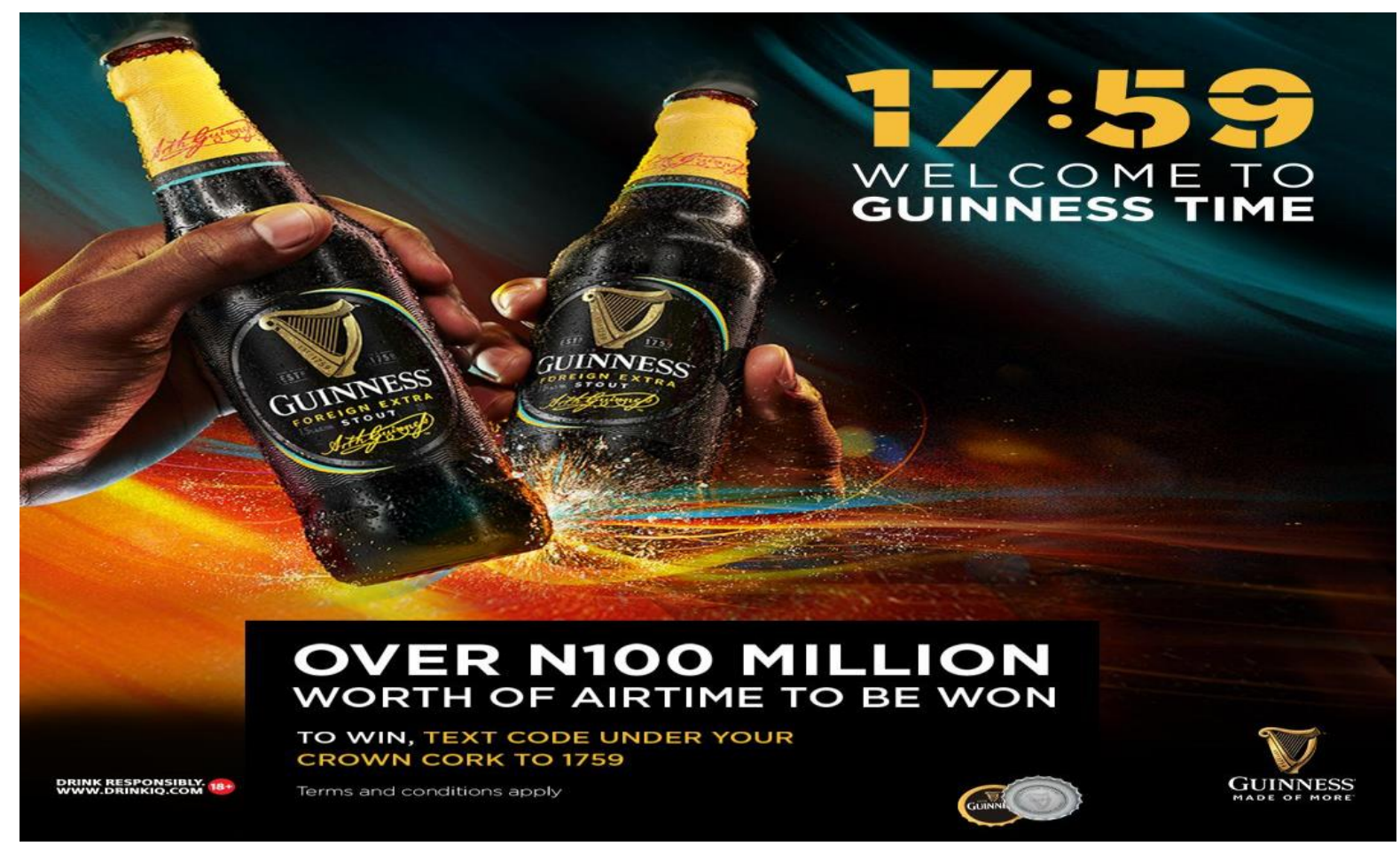

Ad 8

$8 \mathrm{a}$

\begin{tabular}{|l|}
\hline $19: 59$ \\
\hline Give information \\
\hline
\end{tabular}

$8 b$

\begin{tabular}{|l|}
\hline Welcome to Guinness time \\
\hline Minor clause \\
\hline
\end{tabular}

8c Over N100 million worth of airtime to be worn

Give information

\begin{tabular}{|l|}
\hline To win, text code under your crown cork to 17:59 \\
\hline Demand goods- $\&$-services \\
\hline
\end{tabular}

\begin{tabular}{ll|}
$8 \mathrm{e}$ & Terms and conditions apply \\
\hline & Give information \\
\hline
\end{tabular}

\begin{tabular}{l|l|}
\hline$f \quad$ Drink responsibly \\
\hline Demang goods- $\&$-services \\
\hline
\end{tabular}

$8 g$

\begin{tabular}{|l|l|}
\hline www.drinkiq.com & $\mathrm{h} \quad$\begin{tabular}{|l|} 
Guinness made of more \\
\hline Give information
\end{tabular} \\
\hline
\end{tabular}

FIGURE 10. Guiness ad dialogue structures analysis

Two Guinness ${ }^{\circledR}$ bottles, two human hands, two crown corks, and a logo of harp are the represented participants in Ad 8. The designer indicates that two hands, considerable as left and right hands, hold a bottle of Guinness respectively. The right hand perhaps comes out of the water and projects Guinness to consumers. In the same vein, another hand from outside the water showcases a bottle of Guinness to viewers. Surprisingly, as the bottle held with the left hand creates some splashes, touching the water, the positions of the two 
bottles form a v-shape. One significant thing is that the bottles are in a position showing the decorations of the yellowish neck foils and body labels to viewers. These attitudes manifest the signature of Arthur Guinness and the instrument of harp, being the logo of Guinness.

Besides, clearly and boldly written on the body labels are written modes such as the Guinness year of establishment, Guinness being foreign extra stout, and the repeated signature of Arthur Guinness. The neck and body labels are meaningmaking devices, in which some of their contents are littered in the communication. Guinness appears five times in the ad, the signature of Arthur Guinness two times, and the harp apparatus three times. These recurrences of affordances could be the motive for the promoter to claim that Guinness [is] made of more. The reflection of more in this marketing environment might be locating Guinness in a comparative discourse where, following the advertiser, the beer is of a greater degree of qualities than all its equals. More gives Guinness a comparative of better standards than any other in any "beering" setting.

The designer employs the punctuated declarative clause, 17:59, and minor clause, welcome to Guinness time, to expound the reason that two hands (of two people) raise to project Guinness to viewers. The purpose is to remind individuals to obey the Guinness time. Guinness time is 17:59. 17:59, as converted into a time, is a metaphor to represent the year that Arthur Guinness took over the St. James Brewery. The brewer tended to promote Guinness as a perfect, matchless, and flawless accompaniment to an evening which could be spent in relaxation at home, however, with Guinness, an ale beer. In respect to that, Guinness seizes the 17:59 concept as a phenomenon and an opportunity to promote the product. Diageo ${ }^{\circledR}$, then, went ahead in 2008 to partner with LoveFilm.com with a huge amount of five pounds to promote Guinness to the entire world.

Specifically in Nigeria, the 17:59 has been consistent, being a minute before the hour of 8:00pm, calling people to relax their evening with Guinness. This ad represents one of such occasions, exciting viewers that Over N100 million worth of airtime to be won. Thus, drinking Guinness is summarily winning airtime. The communicator conveys To win, text code under your crown cork to 17:59 to readers as a channel of profiting from the promotion, anyway with applicable Terms and conditions. The two crow corks, indicating two different sides, demonstrate the domain of locating the code of winning the airtime. It is salient to observe three contexts of 17:59 operations in this communication. As identified earlier, 17:59 depicts the year of Arthur Guinness taking over of the brewery, the time of Guinness consumption, and a digital domain that receives the winning code(s). The colour of Guinness is black, which has been considered beautiful (Snail 2008, Ortega 2018, Dalamu 2020). It is fascinating for the publicist to have cautioned consumers to Drink responsibly, supported with a channel of counsel explicated as www.drinkiq.com. The same black rules the represented participants of Ad 8 in 
order to illustrate a form of lightness that epitomises seriousness, prestige, and dignity (Pile 1997, Bateman 2014).

\section{RESULTS}

The researcher has used this section to delineate some outcomes of the study regarding the research questions (RQs). The RQs are in four sub-sections, highlighting the results with a combination of qualitative (RQs 1 \& 2) and quantitative (RQs 3 \& 4) analyses.

\subsection{Relationships of Modes in the Advertising Systems (RQ 1)}

The analysis reveals the lexeme, mother, in Ad 1 to be coherent with the image of a mother, indicating the word and picture as referring to the same thing in a relay form (Forceville 2020). It is in the same vein that you pinpoints the image of a child. Similarly, there are the code, ${ }^{*} 737 \#$, that corresponds to a handset language in Ad 3, the illuminating devices in Ad 4 that reflect the written modes of Christmas and New Year as well as Pleasant Surprises that represent the Yuletide season's gifts.

Contrariwise, the exploration acknowledges that Live the good life in Ad 2 is a form of anchor (Bateman 2014; Jewitt 2014) to the image of the lady holding some bags in her hands. Besides the written modes, Eazyloans, no one would have understood the financial details behind the lady's bounties. The researcher notices the same contrast in the relationships between the widest $4 G$ LTE coverage in Nigeria (wordings) and the shape of the Yorùbá garb shown in Ad 5. Moreover, real brewed (written modes) in Ad 6 does not correspond to the massive bottle. As real brewed is connotative to Legend, so are complete richness to the Maltina can in Ad 7, and 17:59 in Ad 8 functions as a metaphor to Guinness. Therefore, some modes (written and pictorial) in MTN and GTB are reciprocal in meaning generation; while some modes of Zenith, StanbicIBTC, Airtel, Legend, Maltina, and Guinness play supportive roles to one another to orchestrate meaning potentials.

\subsection{Cultural Affiliations of the Modes (RQ 2)}

This study exemplifies diverse cultural modes. The semiotic configurations display a family cultural norm, regarding the mother and child relationship, as in Ad 1, festivity, as in Ad 1 and Ad 4, and fashionable appearances as in Ad2 and Ad 5 (Dalamu \& Ogunlusi 2020). There are exhibitions of human-computer mediation in the form of social media chatting, as in Ad 3, riverine domains as in Ad 4 and Ad 5, and religious etiquette as in Ad 4. The analysis further unveils business transactions as in Ad 2 and Ad 3, and marketing promotion as in Ad 8. Significantly, observations propagate Edo attire and Yoruba garb respectively in 
Ad 3 and Ad 5 to excite the target audience; whereas the culture of industrial production, sports, and farming dominate Ad 6 and Ad 7.

\subsection{Cumulative Recurrences}

The current study features the outcomes of the written modes, decorated earlier in Table 1, in two perspectives, as revealed in the components of the dialogue structures in Table 2, below. Consequently, Table 2 is the source of Figure 11 and Figure 12 (Charmaz 2014), being the responses to RQs 1 and 2. 


\begin{tabular}{|c|c|c|c|c|c|c|c|}
\hline \multirow{2}{*}{ Product } & \multirow{2}{*}{$\mathrm{Ad}$} & \multicolumn{4}{|c|}{ Dialogue Structure } & \multirow{2}{*}{$\begin{array}{l}\text { Minor } \\
\text { Clause }\end{array}$} & \multirow{2}{*}{ Total } \\
\hline & & Give Information & Demand Information & Give Goods-\&-Services & Demand Goods-\&-Services & & \\
\hline \multirow{3}{*}{$\underset{\Sigma}{Z}$} & $1 \mathrm{a}$ & 1 & | & $\begin{array}{c}0 \\
0\end{array}$ & 0 & 0 & 1 \\
\hline & $1 \mathrm{~b}$ & 0 & 0 & 0 & 0 & 1 & 1 \\
\hline & $1 \mathrm{c}$ & 0 & 1 & 0 & 0 & 0 & 1 \\
\hline \multirow{7}{*}{ 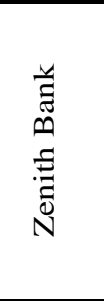 } & $2 a$ & 0 & 0 & 0 & 1 & 0 & 1 \\
\hline & $2 b$ & 0 & 0 & 1 & 0 & 0 & 1 \\
\hline & $2 \mathrm{c}$ & 0 & 0 & 0 & 1 & 0 & 1 \\
\hline & $2 \mathrm{~d}$ & 1 & 0 & 0 & 0 & 0 & 1 \\
\hline & $2 \mathrm{e}$ & 0 & 0 & 0 & 1 & 0 & 1 \\
\hline & $2 \mathrm{f}$ & 1 & 0 & 0 & 0 & 0 & 1 \\
\hline & $2 \mathrm{~g}$ & 1 & 0 & 0 & 0 & 0 & 1 \\
\hline \multirow{7}{*}{$\begin{array}{l}\text { 䒰 } \\
\stackrel{0}{b}\end{array}$} & $3 a$ & 0 & 0 & 0 & 1 & 0 & 1 \\
\hline & $3 b$ & 0 & 0 & 0 & 1 & 0 & 1 \\
\hline & $3 \mathrm{c}$ & 0 & 0 & 0 & 1 & 0 & 1 \\
\hline & $3 \mathrm{~d}$ & 0 & 0 & 0 & 1 & 0 & 1 \\
\hline & $3 \mathrm{e}$ & 0 & 0 & 0 & 1 & 0 & 1 \\
\hline & $3 \mathrm{f}$ & 0 & 0 & 0 & 1 & 0 & 1 \\
\hline & $3 \mathrm{~g}$ & 1 & 0 & 0 & 0 & 0 & 1 \\
\hline \multirow{8}{*}{ 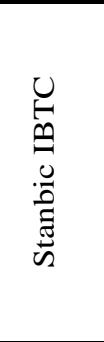 } & $4 \mathrm{a}$ & 1 & 0 & 0 & 0 & 0 & 1 \\
\hline & $4 \mathrm{~b}$ & 0 & 0 & 1 & 0 & 0 & 1 \\
\hline & $4 \mathrm{c}$ & 1 & 0 & 0 & 0 & 0 & 1 \\
\hline & $4 \mathrm{~d}$ & 0 & 0 & 1 & 0 & 0 & 1 \\
\hline & $4 \mathrm{e}$ & 0 & 0 & 0 & 0 & 1 & 1 \\
\hline & $4 \mathrm{f}$ & 0 & 0 & 0 & 1 & 0 & 1 \\
\hline & $4 \mathrm{~g}$ & 1 & 0 & 0 & 0 & 0 & 1 \\
\hline & $4 \mathrm{~h}$ & 0 & 0 & 1 & 0 & 0 & 1 \\
\hline \multirow{4}{*}{ 离 } & $5 \mathrm{a}$ & 1 & 0 & 0 & 0 & 0 & 1 \\
\hline & $5 b$ & 1 & 0 & 0 & 0 & 0 & 1 \\
\hline & $5 \mathrm{c}$ & 0 & 0 & 0 & 1 & 0 & 1 \\
\hline & $5 \mathrm{~d}$ & 1 & 0 & 0 & 0 & 0 & 1 \\
\hline \multirow{7}{*}{ 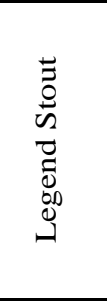 } & $6 \mathrm{a}$ & 0 & 1 & 0 & 0 & 0 & 1 \\
\hline & $6 \mathrm{~b}$ & 1 & 0 & 0 & 0 & 0 & 1 \\
\hline & $6 \mathrm{c}$ & 1 & 0 & 0 & 0 & 0 & 1 \\
\hline & $6 \mathrm{~d}$ & 1 & 0 & 0 & 0 & 0 & 1 \\
\hline & $6 \mathrm{e}$ & 1 & 0 & 0 & 0 & 0 & 1 \\
\hline & $6 \mathrm{f}$ & 1 & 0 & 0 & 0 & 0 & 1 \\
\hline & $6 \mathrm{~g}$ & 1 & 0 & 0 & 0 & 0 & 1 \\
\hline \multirow{2}{*}{ 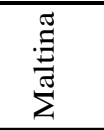 } & $7 \mathrm{a}$ & 0 & 0 & 0 & 1 & 0 & 1 \\
\hline & $7 \mathrm{~b}$ & 1 & 0 & 0 & 0 & 0 & 1 \\
\hline \multirow{8}{*}{ 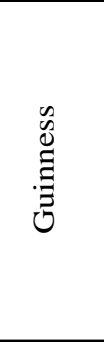 } & $8 \mathrm{a}$ & 1 & 0 & 0 & 0 & 0 & 1 \\
\hline & $8 \mathrm{~b}$ & 0 & 0 & 0 & 0 & 1 & 1 \\
\hline & $8 \mathrm{c}$ & 1 & 0 & 0 & 0 & 0 & 1 \\
\hline & $8 \mathrm{~d}$ & 0 & 0 & 0 & 1 & 0 & 1 \\
\hline & $8 \mathrm{e}$ & 1 & 0 & 0 & 0 & 0 & 1 \\
\hline & $8 \mathrm{f}$ & 0 & 0 & 0 & 1 & 0 & 1 \\
\hline & $8 \mathrm{~g}$ & 1 & 0 & 0 & 0 & 0 & 1 \\
\hline & $8 \mathrm{~h}$ & 1 & 0 & 0 & 0 & 0 & 1 \\
\hline Total & & 23 & 2 & 4 & 14 & 3 & \\
\hline
\end{tabular}

TABLE 2. Analysis of the eight ads' dialogue structures 
Figure 11 and Figure 12 are the synopses of Table 2. The former focuses on the sum-total of the cumulative of the dialogue resources indicated in a vertical form. The latter concentrates on the dialogic components of each product in a horizontal form.

\subsection{Cumulative Recurrence of Dialogue Structures (RQ 3)}

The dialogue resources, as mentioned earlier, are four kinds. That is give information, demand information, give goods-\&-services, and demand goods-\&services. Nonetheless, Figure 11 indicates the minor clause as part of these because a set in English is also a form of dialogue despite that the communicative structure is not within the mood system.

\begin{tabular}{|l|c|}
\hline $\begin{array}{l}\text { Dialogue } \\
\text { Structure }\end{array}$ & Recurrence \\
\hline $\begin{array}{l}\text { Give } \\
\text { Information }\end{array}$ & 23 \\
\hline $\begin{array}{l}\text { Demand } \\
\text { Information }\end{array}$ & 2 \\
\hline $\begin{array}{l}\text { Give Goods- } \& \\
\text { Services }\end{array}$ & 4 \\
\hline $\begin{array}{l}\text { Demand } \\
\text { Goods-\&- } \\
\text { Services }\end{array}$ & 14 \\
\hline Minor Clause & 3 \\
\hline
\end{tabular}

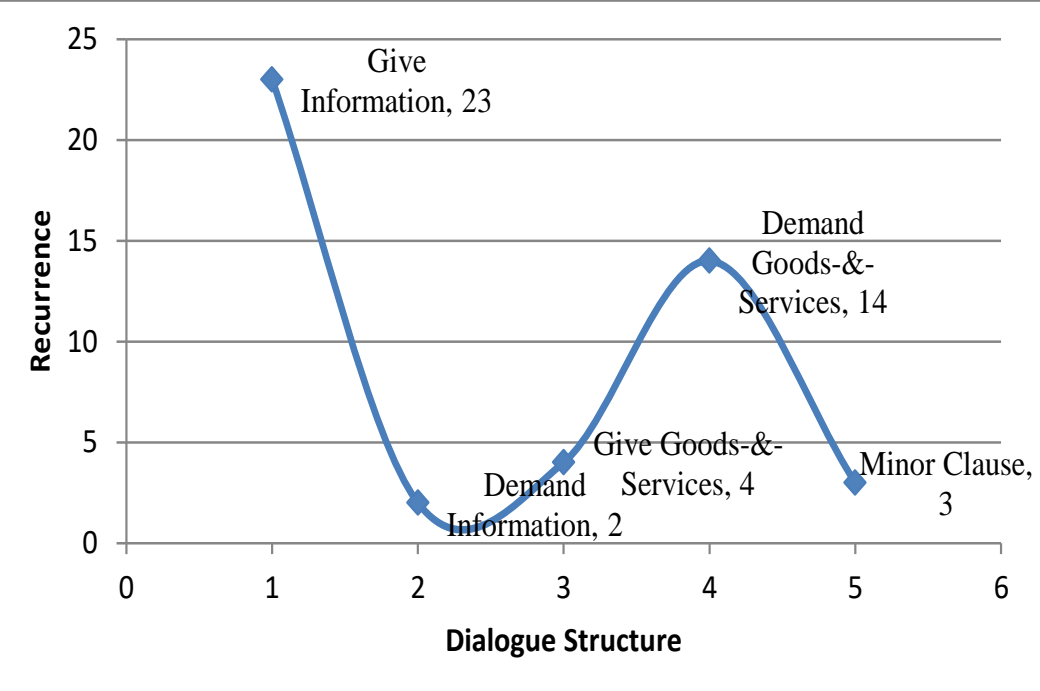

FIGURE 11. Recurrence of dialogue structures in the eight ads

Among the dialogue structures in the analysed ads, Figure 11 describes giving information as the most frequent cumulative strings. This is owing to the 23 points record, shown on the visual table. Demand goods-\&-services cumulative insight is next with 14 points. The statistics scores giving goods-\&services and demanding information within a motivational degree of four and two points correspondingly. In corollary, the researcher might comment that give information - a form of statement and demanding goods-\&-services - a form of command occupy the motivational spheres of genre of ads under investigation. In this case, giving goods-\&-services and demanding information as well as minor clause of three points play some supportive roles.

To elaborate, most of the "interacts" in the ads are declarative and imperative clauses, and neither are serious questions nor politeness in the communications. Advertising practitioners are sometimes rude in communicating the target audience. In spite the claim that customers are kings, 
the meaners seem indirectly to owe viewers no respect when it comes to persuasion to consumption.

\subsection{Recurrence Dialogue Structures of Each Product (RQ 4)}

Every ad has a structure for inspiring readers. Figure 12 acknowledges this argument by explicating the manner of the dialogue structures in each analysed ad.

\begin{tabular}{|l|c|}
\hline \multicolumn{1}{|c|}{ Product } & $\begin{array}{c}\text { Dialogue } \\
\text { Strucure }\end{array}$ \\
\hline MTN & 3 \\
\hline Zenith & 2 \\
\hline GTB & 7 \\
\hline Stanbic & 8 \\
\hline Airtel & 4 \\
\hline Legend & 7 \\
\hline Maltina & 2 \\
\hline Guinness & 8 \\
\hline
\end{tabular}

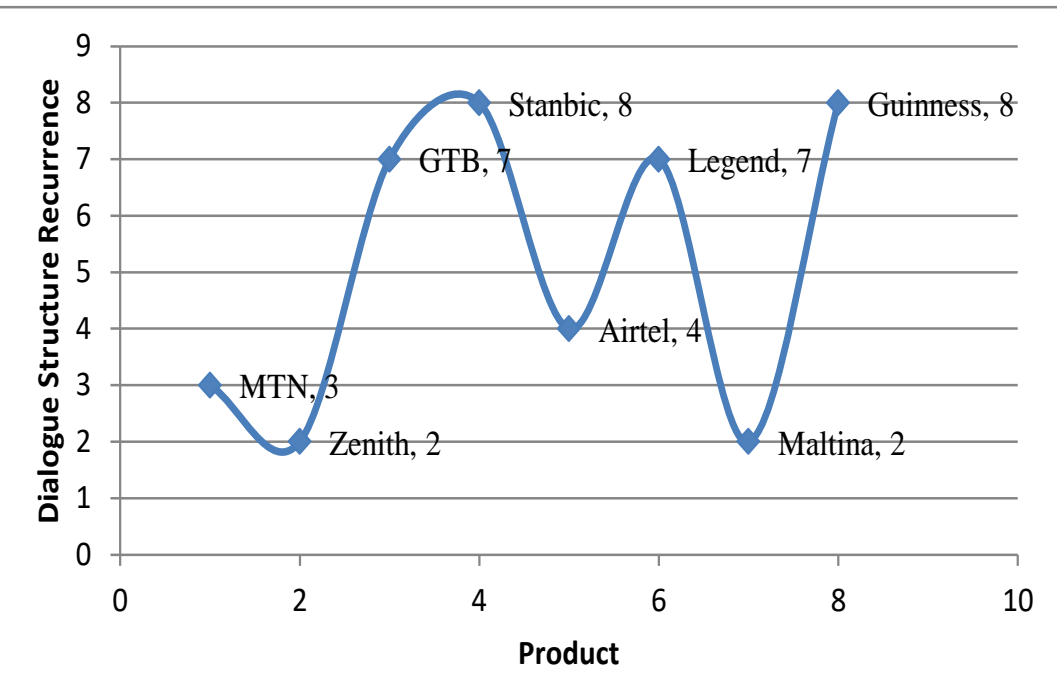

FIGURE 12. Recurrence of dialogue structures in each ad

In this exploration realm, the statistics elucidates Guinness and Stanbic IBTC (of eight dialogue structures each), and GTB and Legend (of seven dialogue structures each) as the products that deploy widest interactional strings. Nonetheless, Airtel and MTN employ four and three dialogue structures harmoniously, while Zenith and Matina utilise two dialogue structures to communicate recipients. With these recurrent establishments, one might remark that designers should learn to avoid the deployment of wordy dialogue structures. Such communicative behaviours tend to bore readers and the intended messages of the ads might be jeopardised. Apt and concise interacts, in the author' opinion, drive the messages home rather than excessive dialogues that drill readers to boredom. Every social actor must consistently understand and reverberate that advertising primarily inspires viewers to consumption of advertised products.

\section{CONCLUSION}

This study has explained that advertising is a social semiotic genre. This is because the communication style displays pictures, words, and colour schemes as interactional modes that convey designers' intended messages. The interplay 
of these semiotic resources generates meanings in such a way to provoke viewers into consumption of products and services.

Subsequently, the application of multimodal communicative acts unveils the kind of affordances in the analysed ads as meaning-makers. There are images of ladies as in Ad 1, Ad 2, and Ad 3; the image of a young man, as in Ad 5; and the images of some products such as Legend bottle, Maltina containers, and Guinness bottles in Ad 6, Ad 7 and Ad 8. These interacts are represented participants. There are written modes of different systems and typographical forms. As the researcher observes big and highlighted fonts (Good Life; Make Money) and deviant coinages (Eazyloans; GTWorld); so also are disjunctive structures (Celebrating the world's no. 1 fixer; Pleasant surprises) and repetitions (Maltina; Guinness; real deal) operational in the framework.

This investigation further illustrates some affordances in codes ( ${ }^{*} 966 \#$; *966*11\#; 737). And specifically, the communicator employs 17:59 to convey three contextual meanings of: a year, time, and channel of assessing promotional benefits. Apart from the pictorial social identification of Lekki-Ikoyi Bridge and Abuja Gate; there are dialogic structural frequencies that certify giving information (statement) and demanding gods-\&-services (command) as the most relevant recurrent dialogic interacts. One might remark that designers could avoid the use of clumsy letterings; the less the wordings, the more the flow of information, and the more readers pay attention to deduce meaning potentials. There is also a need for the creation of eye-lines, vectors, between the represented (human) and interactive (viewers) participants, as displayed in Ad 5. That characteristic behaviour might enhance persuasion to patronise the advertised products.

\section{BIBLIOGRAPHY}

Austin, J. L. (1962), How to Do Things with Words, New York, E. P. Dutton.

BAlDRY, A. \& ThiBAUlt, P. (2006), Multimodal Transcription and Text Analysis: A Multimedia Toolkit and Coursebook, London, Equinox.

BATEMAN, J. (2014), "Review: The Language of Colour: An introduction By Theo van Leeuwen", Linguistics and the Human Sciences, 9(1), 1-8.

BAteman, J., HenschelL, R. \& Delin, J. (n.d.), A Brief Introduction to the GeM Annotation Schema for Complex Document Layout. Available at: <http://www.purl.org/net/gem>. BATEMAN, J. (2008), “Decomposition of Semiotic Modes”, in Multimodal Studies; Exploring Issues and Domains, O'Halloran, K. \& Baldry, S. (eds.), London, Routledge, 17-38.

BATEMAN, J. (2013), "Multimodal Analysis of Film within the GeM Framework", Ilhado Desterro JELLECS, 64, 49-84.

BATEMAN, J. (2014), Text and Image: A Critical Introduction to Visual/Verbal Divide,London, Routledge.

BATEMAN, J., WiLDFEUER, J. \& HiIPALA, T. (2017), Multimodality: Foundations, Research and Analysis, A Problem-Oriented Introduction, Berlin, De Gruyter Mouton. 
BAWARSHI, A. \& MARY, J. R. (2010), Genre: An Introduction to History, Theory, Research, and Pedagogy, West Lafayette, Indiana, Parlor Press. Available at: $<$ https://wac.colostate.edu/books/bawarshi_reiff/genre.pdf $>$.

Berger, P. \& Luckmann, T. (1966), The Social Construction of Reality: A Treatise in the Sociology of Knowledge, New York, Doubleday.

BhatiA, V. K. (1993), Analysing Genre: Language Use in Professional Settings, Harlow, Longman.

BHATIA, V. K. (2002), “Applied Genre Analysis: A Multi-Perspective Model”, IBÉRICA, 4, 3-19.

BHAtiA, V. K. (2008), "Genre Analysis, ESP and Professional Practice", English for Specific Purposes, 27, 161-174.

BlOOR, T. \& BlOOR, M. (2013), The Functional Analysis of English, Abingdon, Oxon, Routledge.

CAMbria, M., ARIZZI, C. \& CocCetTA, F. (2012), Web Genres and Web Tools, Bolton, IBIS. Available at: $<$ www.ibisedizioni.it $>$.

CHARMAZ, K. C. (2014), Constructing Grounded Theory, Thousand Oaks, CA, SAGE.

CHIAZZARI, S. (1998), The Complete Book of Color, Boston, Elements Books Ltd.

COOK, G. (2001), The Discourse of Advertising, New York, Routledge.

CRYSTAL, D. (1991), A Dictionary of Linguistics and Phonetics, Oxford, Basil Blackwell.

DalamU, T. O. (2018), “Evaluating 'Registerial' Norms in Advertising Texts: A Systemic Perspective", Buckingham Journal of Language and Linguistics, 11, 64-97.

DALAMU, T. O. (2019a), “Halliday's Mood System: A Scorecard of Literacy in the English Grammar in an L2 Situation", RELIN, 27(1), 241-274.

DALAMU, T. O. (2019b), "Illuminating Systemic Functional Grammatics as a Viable Tool of Digital Humanities", Digital Studies/le champ numerique, 9(1): 8, 1-50.

Dalamu, T. O. (2019c), “Textual Artifact of Advertising: A Thrust of Halliday's Mood System Resources", Revista Brasileira de Linguística Aplicada, 19(3), 407-454.

DAlAMU, T. O. (2020), "Black: A Persuasive Metaphor in Guinness Stout's Advertisements in Nigeria", Revista de Humanudades, 40, 37-68.

Dalamu, T. O. \& OGUnlusi, G. (2020), "Revitalising Cultural Characteristics in Advertising in Nigeria within a Sketch of Systemic Paradigm", Anagramas Rumbos Y Sentidos De La Comunicación, 19(37), 13-48.

DE MoOIJ, M. (2015), “Cross-cultural Research in International Marketing: Clearing up Some of the Confusion", International Marketing Review, 32(6), 646-662. Available at: <https://doi.org/10.1108/IMR-12-2014-0376>.

DEVITT, A. (2008), Writing Genres, Illinois, Southern Illinois University Press.

DEVITT, A. J. (2009), “Teaching critical genre awareness", in Genre in a changing world Bazerman, C. \& Figueiredo, D. (eds.), Fort Collins, Bonini, The WAC Clearinghouse and Parlor Press, 337-351.

EGGINS, S. (2004), Introduction to Systemic Functional Linguistics, London, Continuum.

ENGELBRECHT, K. (2003), The Impact of Colour on Learning, Chicago, Perkins \& Will.

EzeIGBO, T. (1998), A Companion to the Novel, Ikoyi-Lagos, Vista Books.

FORCEVILLE, C. (1996), Pictorial Metaphor in Advertising, London, Routledge.

ForCeVILle, C. (2020), Visual and Multimodal Communication: Applying the Relevance Principle, Oxford, Oxford University Press.

GIESZINGER, S. (2001), The History of Advertising Language, Frankfurt, Peter Lang GmbH. 
GuO-WEI, R. (2010), "Text, genre and multi-genre", Studies in Literature and Language, $1(7), 82-88$.

HALL, E. T. (1976), Beyond Culture, Anchor Book, Doubleday.

HallidAy, M. A. K. (1995), An Introduction To Functional Grammar, London, Arnold.

HALLIDAY, M. A. K. \& HASAN, R. (1976), Cohesion in English, England, Longman.

HALLIDAY, M. A. K. \& HASAN, R. (1985), Language Context and Text: Aspects of Language in a Social Semiotic Perspective, Oxford, Oxford University Press.

Halliday, M. A. K. \& MATTHIESSEN, C. (2014), Halliday's Introduction to Functional Grammar, Abingdon, Oxon, Routledge.

Heller, E. (2009), Psychologie de la Couleur: Effets et Symboliques, Paris, Pyramyd.

HiIPPALA, T. (2014), "Multimodal genre analysis", in Interactions, Images and Texts: A Reader in Multimodality, Norris, S., Carmen D. \& Maier, C. D. (eds.), 111-123.

Hofstede, G. \& Hofstede, G. J. (2005), Cultures and Organizations: Software of the Mind, New York, McGraw-Hill.

HYlAnD, K. (2004), Disciplinary Discourses: Social Interactions in Academic Writing, Michigan, University of Michigan Press.

HYLAND, K. (2007), “Genre Pedagogy: Language, Literacy and L2 Writing Instruction”, Journal of Second Language Writing, 16(3), 148-164.

HYLAND, K. (2012), “English for academic purposes and discourse análisis introduction", in The Routledge Handbook of Discourse Analysis, Gee, J. P. \& Handford, M. (eds.), London, Routledge, 412-423.

JAWORSKI, A. \& COUPLAND, N. (eds.) (2006), The Discourse Reader, New York, Routledge. JeWITT, C. (ed.) (2009), The Routledge Handbook of Multimodal Analysis (1st ed.), London, Routledge.

JEWITT, C. (ed.) (2014), The Routledge Handbook of Multimodal Analysis (2nd ed.), London, Routledge.

JEWITT, C., BEZEMER, J. \& O'HALLORAN, K. (2016), Introducing multimodality, London, Routledge.

KOSKI, K., FROG, U. S. \& SKS (2016), “Genre - text - interpretation: multidisciplinary perspectives on folklore and beyond", Helsinki: Finnish Literature Society, SKS.

KRESS, G. \& VAN LEEUWEN, T. (2002), “Colour As a Semiotic Mode: Notes for a Grammar of Colour", Visual Communication, 1(3), 343-368.

KRess, G., \& VAN LeEuWEN, T. (2006), Reading Images: The Grammar of Visual Design, London, Routledge.

KRESS, G., \& VAN LeEUWEN, T. (2021), Reading Images: The Grammar of Visual Design, London, Routledge.

LECKIE-TARRY, H. (1993), “The specification of text: Register, genre and language teaching", in Register Analysis: Theory And Practice, Ghadessy, M. (ed.), London, Pinter Publisher, 26-42.

LEE, D. Y. W. (2010), “Genres, Registers, Text Types, Domains, and Styles: Clarifying the Concepts and Navigating a Path Through the BNC Jungle", Language Learning $\mathcal{E}$ Technology, 5(3), 37-72.

MARTIN, J. R. (2009), “Genre and Language Learning: A Social Semiotic Perspective”, Linguistics and Education, 20(1), 10-21.

MARTIN, J. R. \& ROSE, D. (2009), Genre Relations: Mapping Culture, London, Equinox.

MARTIN, J. R. \& Rose, C. (2013), Working With Discourse: Meaning Beyond The Clause, New York, Bloomsbury Academy. 
MAXWELL, J. A. (2013), Qualitative Research Design: An Interactive Approach, London, SAGE. MYERS, G. (1994), Words in Ads, London, Arnold.

NORRIS, S. (2013), "Multimodal (Inter)action Analysis: An Integrative Methodology", in Body - Language - Communication: An International Handbook on Multimodality in Human Interaction, Müller, C., Cienki, A., Fricke, E., Ladewig, S., McNeill, D. \& Teßendorf, S. (eds.), Bremen, de Gruyter Mouton, vol. 1, 275-286.

NWINLAARU, I. N. (2021), "Towards a Meta-Theory of Genre”, in Approaches to Specialised Genres, Ling Lin, K., Nwinlaaru, I. \& Tay, D. (eds.), London, Routledge, 17-35. Available at: $<$ https;//www.ebsco.com/terms-of-use $>$.

OrtegA, M. (2018), "Black Is Beautiful: A Philosophy of Black Aesthetics by Paul C. Taylor", Critical Philosophy of Race, 6(2), 287-292.

OsoBA, B. (2012), "An analysis of intra-city patterns of residents in Lagos Metropolis, Nigeria", International Journal of Development and Sustainability, 1(2), 563-580. Available at: $<$ https://isdsnet.com/ijds-v1n2-38.pdf $>$.

PATTON, M. (2015), Qualitative Research and Evaluation Methods: Integrating Theory and Practice, Thousand Oaks, SAGE.

PÉRez Flores, A. M. \& MuÑos SÁnCHEZ, V. M. (2018), “Deporte, Cultura y Sociedad: Un Estado Actual de la Cuestión," Revista de Humanidades, 34, 11-38. Available at: $<$ https://dialnet.unirioja.es/descarga/articulo/6462051.pdf >

RAVELLI, L. (2019), "Multimodality and the Register of Disciplinary History: Challenges for New Texts and Old Theories," Language, Context and Text, 1, 341-365.

SNAIL, M. (2008) "The Black Consciousness Movement in South Africa: A Product of the Entire Black World," Historia Actual Online, 15, 51-68.

SWALES, J. M. (1990), Genre Analysis: English in Academic and Research Settings, Cambridge, Cambridge University Press.

TARDY, C. M. (2016), Beyond Convention: Genre Innovation in Academic Writing, Michigan, University of Michigan Press.

THOMSON, G. (2014), Introducing Functional Grammar, London, Hodder Arnold.

VAN LEEUWEN, T. (2005), Introducing Social Semiotics, London, Routledge.

VAN LEEUWEN, T. (2011), The Language of Colour, London, Routledge.

VestergaARD, T. \& SCHRODER, K. (1985), The Language of Advertising, Oxford, Basil Blackwell.

WiLliAMSON, J. (2002), Decoding Advertising: Ideology and Meaning in Advertising, New York, Marion Boyars.

WORDEN, D. (2015), “Developing Writing Concepts for Teaching Purposes: Pre-ervice L2 Writing Teachers' Developing Conceptual Understanding Of Parallelism", Journal of Second Language Writing, 30, 19-30.

YANCEY, K., ROBERTSON, L. \& TACZAK, K. (2014), Writing Across Contexts: Transfer, Composition, and Sites of Writing, Colorado, Colorado State University Press. 